\title{
TELL KHAIBER: AN ADMINISTRATIVE CENTRE OF THE SEALAND PERIOD ${ }^{1}$
}

\author{
By Stuart CAmpbell, Jane Moon, Robert Killick, Daniel CAlderbank, \\ ELEANOR ROBSON, MARY SHEPPERSON AND FAY SLATER
}

Excavations at Tell Khaiber in southern Iraq by the Ur Region Archaeological Project have revealed a substantial building (hereafter the Public Building) dating to the mid-second millennium B.c. The results are significant for the light they shed on Babylonian provincial administration, particularly of food production, for revealing a previously unknown type of fortified monumental building, and for producing a dated archive, in context, of the little-understood Sealand Dynasty. The project also represents a return of British field archaeology to long-neglected Babylonia, in collaboration with Iraq's State Board for Antiquities and Heritage. Comments on the historical background and physical location of Tell Khaiber are followed by discussion of the form and function of the Public Building. Preliminary analysis of the associated archive provides insights into the social milieu of the time. Aspects of the material culture, including pottery, are also discussed.

\section{Historical background}

The loss of control of southern Babylonia by the First Dynasty of Babylon and the history of the Sealand kings form particularly obscure episodes of Mesopotamian history. The complex and debated chronology ${ }^{2}$ as well as the political circumstances are impossible to disentangle fully with current information. ${ }^{3}$ Periodic collapse of central states is a recurrent theme both in Mesopotamia and in many other early complex societies, ${ }^{4}$ but the specific narratives are much harder to understand. In the case of the First Dynasty of Babylon, there are certainly historical indications of external pressures from Kassites and Hittites, but internal stress and systemic failings should also be taken into account. Environmental degradation has also been proposed as a factor. However, collapse of societies is often incomplete and the narrative of grand politics simplifies and overlooks the detail of the social impact. The trajectories of individual regions and local communities may vary considerably and include resistance as well as successful adaptation to more general collapse. All this requires a much more nuanced understanding than simply following the rise and fall of centralising dynasties.

Since Elizabeth Stone's ground-breaking article was published in 1977, it has generally been believed that the major urban centres of southern Babylonia were abandoned during the centuries following the collapse of central control by the Babylonian kings. ${ }^{5}$ Until quite recently there has been relatively little new information about this period but, in 2009, 474 unprovenanced tablets from the Sealand Dynasty were published by Stephanie Dalley, who argued on the basis of these

\footnotetext{
${ }^{1}$ We gratefully acknowledge the support, above all, of Baron Lorne Thyssen-Bornemisza at The Augustus Foundation, also of the British Institute for the Study of Iraq, and the Gerald Averay Wainwright Fund for Near Eastern Archaeology.

Our thanks also to the following companies and institutions who have generously contributed to our work at Tell Khaiber, through donations and/or help-in-kind: the British Council, Iraq; Foreign and Commonwealth Office and the British Embassy, Iraq; BSOC; DigitalGlobe Foundation; Gulfsands Petroleum Ltd; IKB Travel; Kirintec Ltd, Niton UK; SKA International Group; and Unity Resources Group. And similarly to the following individuals: Renate de Kleine Stephenson, Spindrift Al-Suwaidi, and Sue and Bill Rees.

We are also grateful to colleagues and staff at the State Board for Antiquities and Heritage, Iraq, for their invaluable
}

assistance, especially Mr Qais Hussein Rashid, Dr Ahmad Kamil, Dr Haider al-Mamori, Dr Abdulamir Hamdani and Mr Ali Kadhim; to John MacGinnis for his preliminary work on the tablets from the 2014 season; to Andrew George and Niek Veldhuis for their expert advice on particular readings; and to Michael Roaf for commenting on a draft of this article. As usual, any remaining errors can be ascribed to the authors.

${ }^{2}$ Gasche et al. 1998; Charpin 2004; Roaf 2012. We do not address the complex and unresolved matter of second millennium chronology here. All dates in this interim report follow the Middle Chronology, which dates the fall of Babylon to $c .1600$ B.C.

3 van Koppen 2010.

${ }^{4}$ Yoffee and Cowgill 1988; McAnany and Yoffee 2010.

${ }^{5}$ Stone 1977; Gasche 1989; more recently e.g. van de Mieroop 2015: 123. 


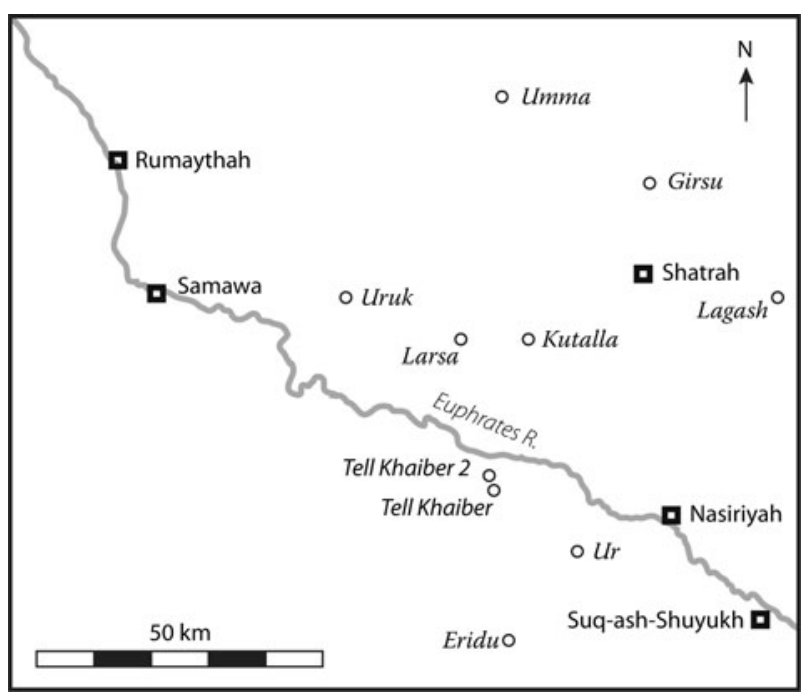

Fig. 1 Location of Tell Khaiber and Tell Khaiber 2

texts in favour of continuity of elite residences and cult centres at many of the traditional urban centres of southern Mesopotamia. ${ }^{6}$ At the same time, field archaeology in southern Iraq has undergone a long hiatus. Although Iraqi archaeologists have conducted some notable excavations, often against a background of extensive looting and site destruction, the input of international archaeological projects that formed a key component of the investigation of southern Mesopotamia has been disrupted since the 1980s. It is only very recently that external co-operation in fieldwork in the area has become possible. ${ }^{7}$

It is in this context that the recent excavations at Tell Khaiber gain particular significance. The project, which has now carried out three seasons of excavation between 2013 and 2015, has focused on the excavation of a large institutional building dating to the mid-second millennium B.C. This is the first time that substantial occupation during the time of the Sealand Dynasty has been identified and excavated.

Tell Khaiber was selected for excavation because it met the following criteria: satellite images suggested the presence of coherent architecture near the surface; there was no recent significant damage or looting; all of the periods represented by surface pottery posed potential research questions for this area, and the mounds are accessible, lying in an area considered safe by the Iraqi authorities. An overarching aim was also to help re-connect the professional and academic archaeologists of southern Iraq with their international colleagues.

\section{Tell Khaiber}

Tell Khaiber lies thirteen kilometres west of Nasiriyah in Iraq's Thi Qar province. It is approximately nineteen kilometres north-west of Ur, and twenty-five kilometres south of Larsa (Fig. 1). The toponym "Tell Khaiber" in fact applies to two separate mounds, both part of the same archaeological landscape. ${ }^{8}$ They are of similar size, both approximately c. $300 \times 250$ metres in extent. The focus of excavation has been Tell Khaiber, where the main period of extant occupation dates to the Sealand Dynasty. The other mound (Tell Khaiber 2) lies about one kilometre to the

\footnotetext{
${ }^{6}$ Dalley 2009: 5-9.

${ }^{7}$ Only at Tell Khaiber and at Abu Tbeirah (by La Sapienza University, Rome) have more than short investigations been conducted, but as of 2015, this situation is improving.

${ }^{8}$ As the mounds have been given multiple and sometimes contradictory names in the recent past, the project has adopted the simple designations "Tell Khaiber" and "Tell Khaiber 2". Both mounds were first documented by Henry
}

Wright in the Eridu-Ur regional survey in 1965-6 (Wright 1981), in which Tell Khaiber is site 60, named Ishan Khaiber, while Tell Khaiber 2 is site 61, named Tell Gurra. In the Atlas of the Archaeological Sites of Iraq, Directorate General of Antiquities, Ministry of Information, Iraq 1976, both sites are called Ishan Khaiber (Map 73: Site 108 Ishan Khaiber $=$ Tell Khaiber; Site 107 Ishan Khaiber $=$ Tell Khaiber 2). 


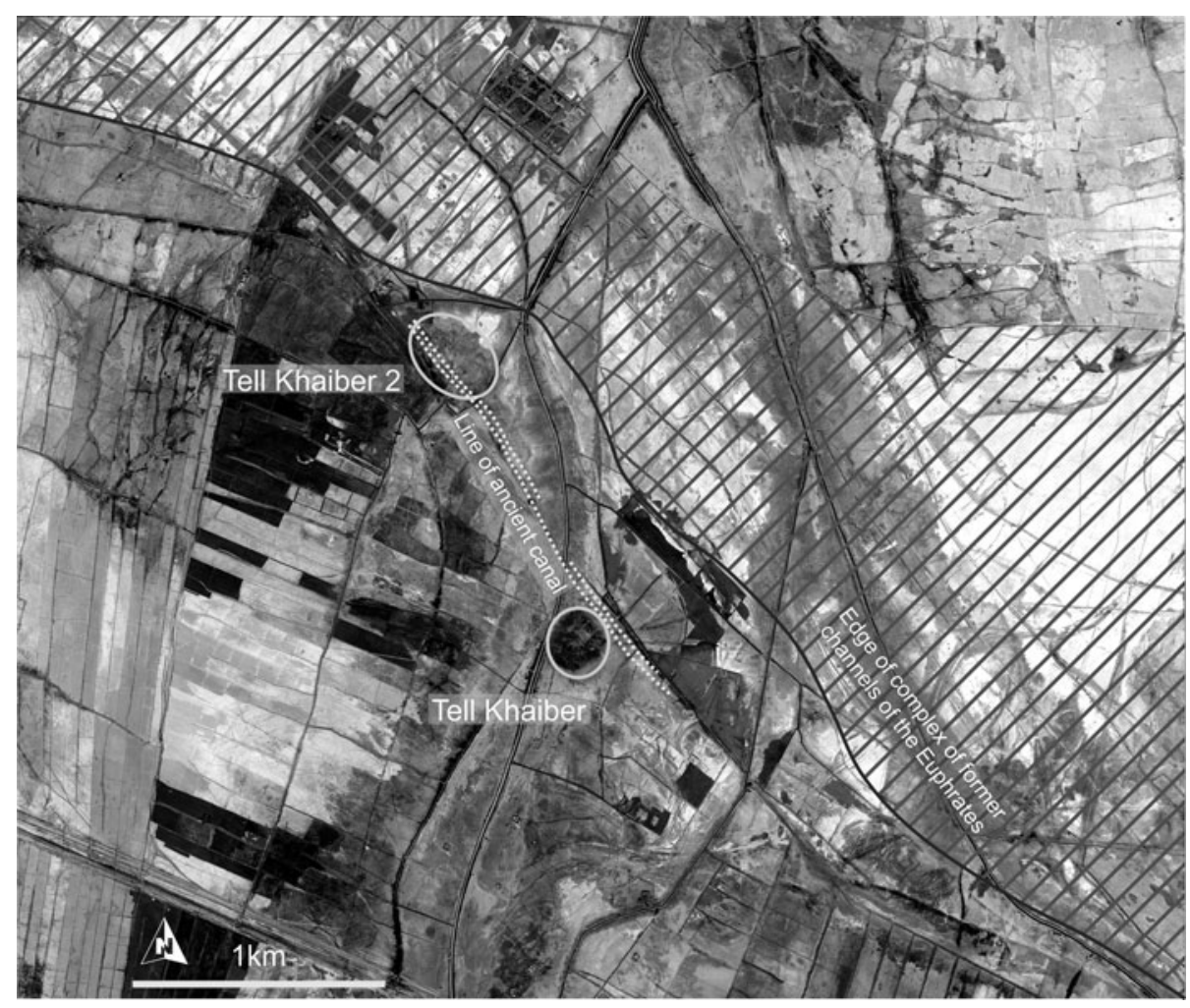

Fig. 2 River courses and canals. Satellite image 24/12/2010. Image courtesy of the DigitalGlobe Foundation

north-west and is not contemporary, dating to the Kassite period. It has been the subject of very limited investigation consisting of surface mapping and three soundings.

The Khaiber mounds are situated close to an old branch of the Euphrates that runs to the south-west of its present course (Fig. 2). This branch forms part of the Ur channels of the Euphrates that, together with the Eridu channel which took off from the river further west, supported the extensive settlement of this area during the Old Babylonian period. ${ }^{9}$ It would appear that the river continued in the same course in the later second millennium. Two parallel relict canals, probably taking off from the Euphrates to the north of the Khaiber mounds, are visible on the ground (marked with dotted white lines on Fig. 2). ${ }^{10}$ They run between the low mounds of Tell Khaiber 2, immediately adjacent to a large building visible in satellite images, and then continue past the northern edge of Tell Khaiber before heading south-west. While the direct dating of the canal remains to be confirmed, one sounding at Tell Khaiber 2 suggested that it was cut from the same surface that has occupation associated with Kassite pottery and the upcast from its fill also contained characteristic Kassite ceramics. Our current hypothesis is that the same canal system served both settlements and remained in use throughout the Sealand Dynasty and the succeeding period.

All the archaeological layers investigated at Tell Khaiber are from the mid-second millennium B.C. but there is clear evidence of earlier occupation at the site from re-deposited pottery on the surface and in the fill of the second millennium buildings. The earliest material consists of a handful of painted sherds, which are Ubaid 3-4 in date. There are small quantities of Jemdet Nasr (and possibly also Late Uruk) ceramics and a substantial corpus of Early Dynastic pottery. ${ }^{11}$ There are also hints of Ur III activity, including fragments of three burnt bricks with inscriptions of Amar-Sin, although

\footnotetext{
${ }^{9}$ Wright 1981: 330; Pournelle 2003: fig. 26.

${ }^{10}$ Two clearly distinct canal lines are visible at Tell Khaiber 2, each 15-20 metres wide and running adjacent to each other: they are presumably successive recuts of the same canal.
}

\footnotetext{
${ }^{11}$ The pre-second millennium B.C. pottery is treated in Calderbank and Moon 2016
} 


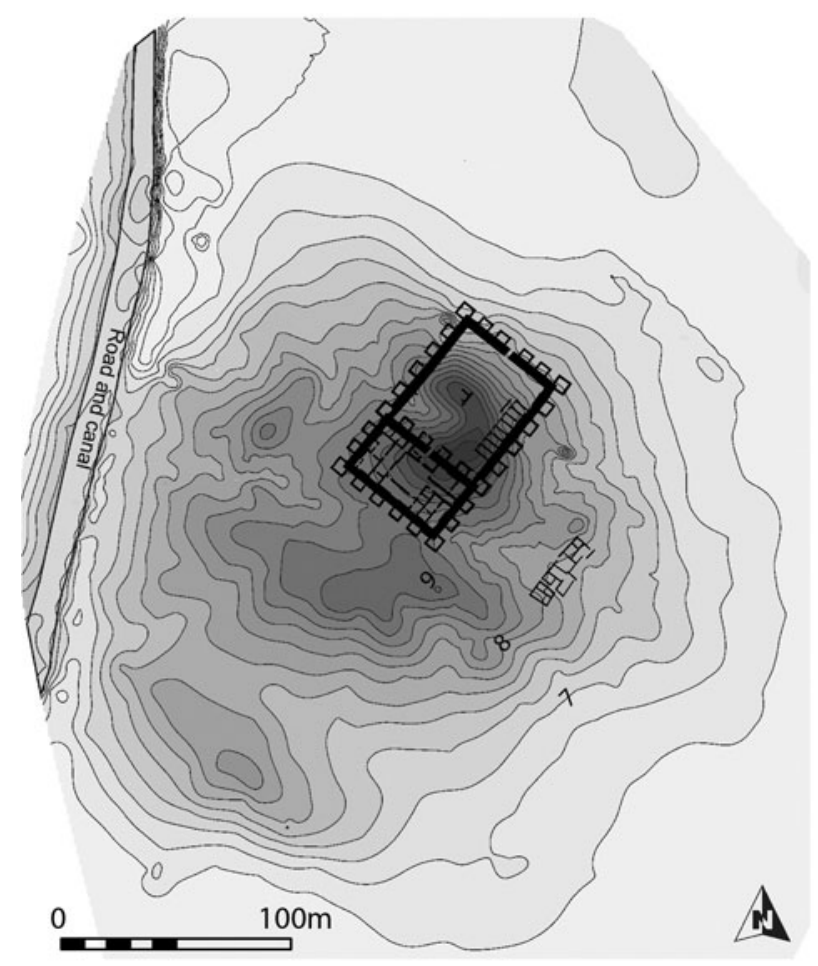

Fig. 3 Contour map of Tell Khaiber. Arbitrary datum $+10 \mathrm{~m}, 20 \mathrm{~cm}$ intervals

it is possible these might have been brought from elsewhere in antiquity. While in situ material from some or all of these earlier periods may survive intact at the site, some beneath the present water table, none has so far been excavated. The large-scale second millennium construction at Tell Khaiber probably destroyed substantial amounts of earlier occupation during levelling on the north-eastern part of the site as well as providing large quantities of debris re-deposited in later contexts. A small, square burnt brick structure of uncertain date on the south-eastern slope of the mound is the only evidence for later activity at the site.

The Public Building at Tell Khaiber occupies a substantial part of the north-east of the site (Fig. 3). A small cluster of buildings to its south is visible on satellite images, separated by what may have been an open area and probably representing domestic houses. Although the remainder of the site has produced no clear wall lines, surface collections in 2013 and survey of transects across the mound in 2015 to evaluate soil chemistry provide a better understanding of the settlement configuration. A row of low humps lies to the north-west of the Public Building with particularly high concentrations of slag, probably from ceramic production, and low indications of organic material in the soil chemistry suggest that these may be composed of waste from industrial production. The surface pottery from the south-western half of the site seems to belong to the same general period as the main building and probably represents an area of housing or other activities that is contemporary with the Public Building. However, its total extent is not much greater than that of the large structure itself, suggesting that the settlement was dominated by the Public Building, with the other occupied areas perhaps representing a mixture of functions, including population overflow from the main structure, ancillary dwellings for individuals loosely attached to it, and perhaps craft, storage and production areas for activities that could not be easily or pleasantly accommodated within the Public Building.

\section{The Public Building}

The Public Building covers approximately 4,400 square metres. About one third of its plan has been recovered so far through surface scraping, and fourteen rooms or areas have been excavated in whole 


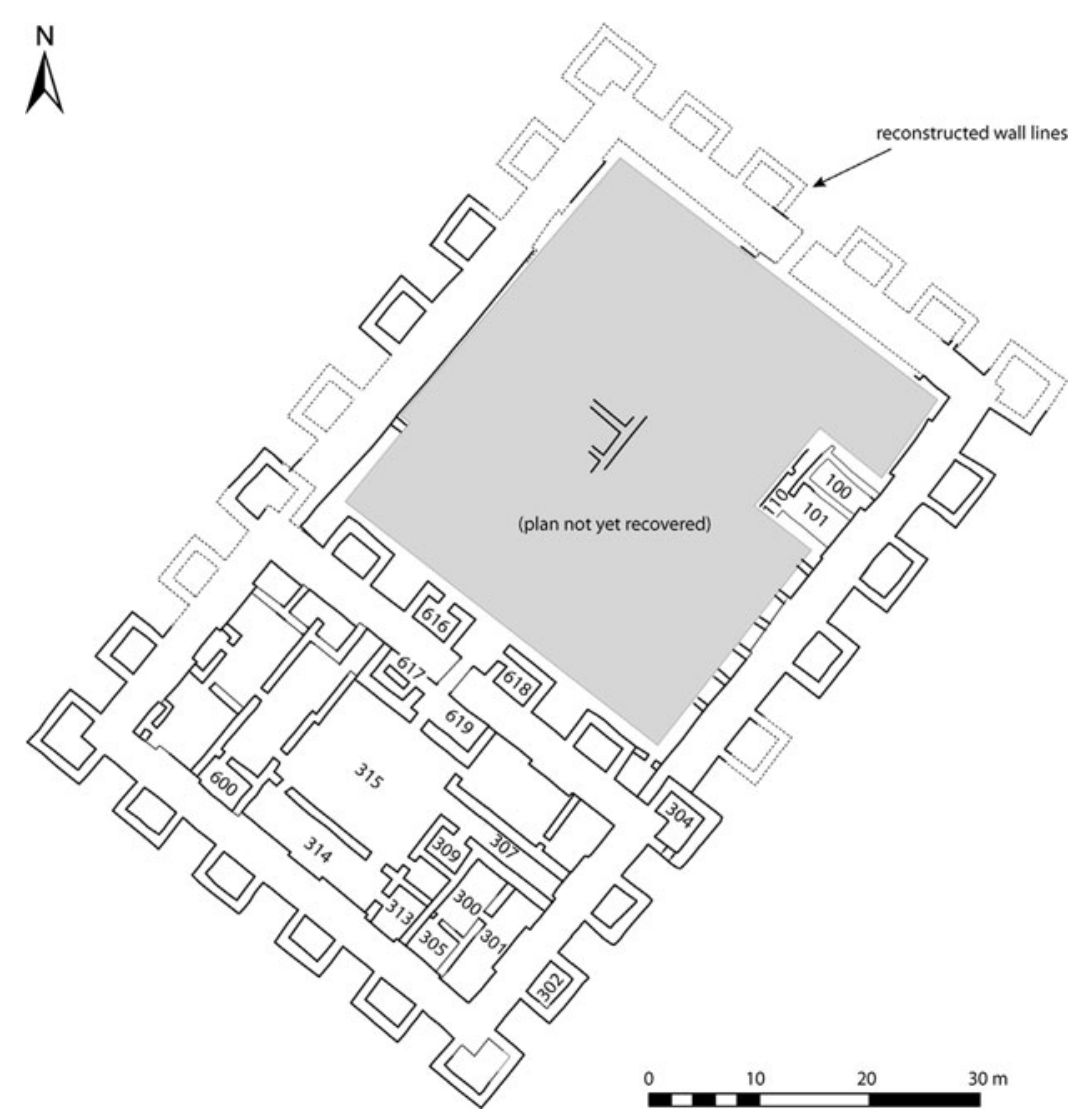

Fig. 4 The Public Building at Tell Khaiber

or in part (Fig. 4). The extant archaeological deposits, which have a maximum depth of one and a half metres over the central part and considerably less (as little as thirty to forty centimetres) on the periphery, represent the earlier part of the building's history. It has clearly suffered from extensive erosion and one or more later phases of occupation must have been lost, as across some of the highest areas of the mound plastered surfaces and installations such as ovens lie directly under the surface.

The southern third of the building was originally free standing and is the oldest part. Subsequently, the Public Building was enlarged considerably on the north-eastern side. We cannot at present say much about how this sequence is reflected in the actual archaeological deposits. Where we have investigated the relationship between the two structures there is a difference in height of only thirty centimetres (over a distance of sixty-five metres) between the bottom of the walls of the original building and those of the extension. Curiously it is the walls of the latter that stand lower. This could be due to the contours of the third millennium mound or perhaps to pre-construction levelling. It is a point that requires further investigation, as does the relative stratigraphy of the two parts of the building as a whole.

In its earliest form, the Public Building was a rectangular block approximately $53 \times 27.5$ metres, with an external wall 3.3 metres wide and a single narrow entrance on the north-eastern side. On the corners of this block, and arranged at regular intervals along all four external sides, are what appear to be hollow projecting towers with matching shallow internal buttresses (Fig. 5). These are integral to the earliest phase of the building: excavation against the external face of the main wall on the north-west side showed that both the main wall and the walls of the towers were built on the same surface.

The entire south-western part of the building has been surface scraped and this has resulted in the recovery of the overall plan, although some of the details, such as some interconnecting doorways and 


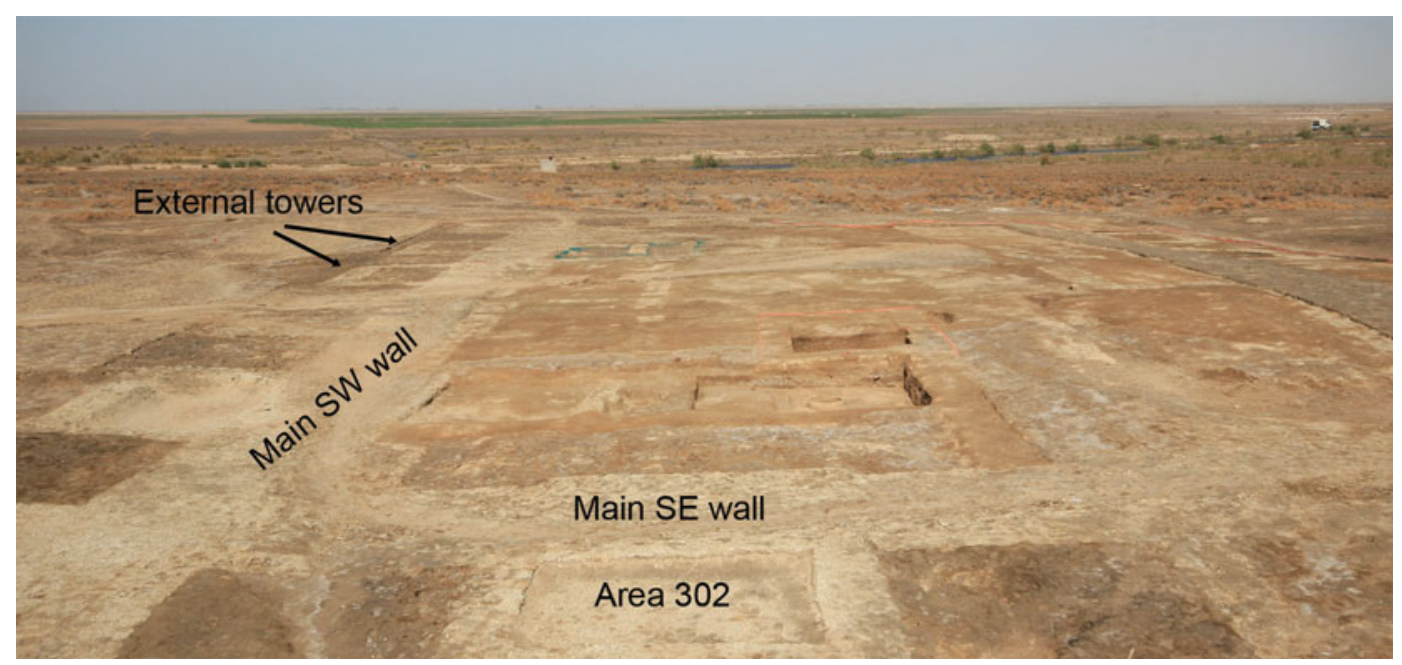

Fig. 5 The Public Building, from the south-east side, looking northwest

wall junctions, remain unclear. Elements of the internal plan of this part of the building are typical of Old Babylonian domestic architecture, even if we cannot find parallels for the whole. ${ }^{12}$ Thus we can recognise an antechamber (Area 619) that restricts access to the central courtyard (Area 315), while to the right of the entrance is a room with a free-standing block of brickwork (Area 617), perhaps a bench or support for steps to an upper floor or roof. On the opposite side of the courtyard from the antechamber is a candidate for the main reception room (Area 314). Off the reception room is a small private space (Area 313). On the north western side of the courtyard is a suite of rooms, unexcavated except for Area 600, which might represent the domestic wing.

Some of the rooms on the south-eastern side had an administrative function: cuneiform tablets have been found in three rooms so far, Areas 300, 305 and 309, all of which are still under excavation. Most of the tablets are from Area 300 where they appear to have been stored. In the northern part of this room was a roughly circular clay bin where tablets were recycled and the clay reused. Access to this room remains unclear. Doors into the adjacent rooms to the south, Areas 301 and 305, have been identified but not yet one that would lead directly or indirectly out into the main courtyard (Area 315) and to the exit.

The building was then enlarged to the north-east, giving it overall dimensions of $53 \times 83$ metres. The secondary nature of this addition is clearly illustrated by the brickwork abutting the external room (Area 304) on the eastern corner of the original building (Fig. 4). The new building repeated some of the features of the old, including the arrangement of a massive perimeter wall and external towers with matching shallow internal buttresses. The entrance to the enlarged building has yet to be identified. Surface scraping has shown that it must lie on the north-eastern side. This is a badly eroded part of the building but preliminary indications suggest a single entrance in the middle of a towered façade like those on the other sides of the building.

The internal plan of the north-eastern addition has yet to be recovered except for a row of identical rooms along the south-eastern side. These were originally thought to be store rooms, but the one excavated so far (Area 101) has a sequence of tannurs next to the doorway, including one on the earliest floor, which suggests otherwise. Surface scraping of the adjacent room also indicated a tannur in a similar position so this may be typical of these rooms. It is clear from the pattern of abutments that, as with the earlier part of the Public Building, the external wall was completed before work started on the internal rooms. However, excavation at the junction of one of the internal walls of Area 101 with the main external wall showed that both were built from the same

12 Jahn 2005; Miglus 1999. 
surface, without any intervening deposits accumulating against the main wall prior to construction of the internal walls.

One of the most striking features of the overall plan is the arrangement of external towers around the outside (Fig. 4), for which we have not found any parallels. Three have been excavated to date and Area 302 along the south-eastern side is a typical example. Here, the one metre thick walls enclose a floor space of just under nine square metres. An internal brick pavement continued under the walls of the tower, suggesting that it also provided a platform for the construction of the tower walls. Above the pavement was a distinctive dark deposit, notably rich in pottery fragments and animal bones. Several objects lay close to the main wall in the north corner, including a baked clay cylinder seal (see below, 3025:22, Fig. 10), ${ }^{13}$ a bronze spatula (see below, 3025:23) and six stone tools, mostly pounders. Here, as in most of the other external towers, there is no visible access to the internal space. In many cases, this might be because the walls are not preserved to threshold height. The surface scraping has revealed doors in two towers (Areas 616 and 618) where the walls are preserved higher, but both of these are on the side of the original building that was subsequently enclosed when the extension was added and without excavation we cannot state that these entrances are part of the original build. The clearest evidence that the internal space of the towers was accessible and utilised comes from Area 304. This was an external corner tower that became part of the extended eastern façade when the building was enlarged. Inside, the main part of the room had a plastered floor. In the western corner a small area with a mud-brick floor was enclosed by a thin partition wall, functioning perhaps as a storage bin. So clearly the space within the tower was being used and was accessible, perhaps via a ladder from a higher storey. There is a possible doorway in the south-western wall but further work is needed to confirm this and to determine if it is part of the original build.

The space immediately around the building seems to have been devoid of any other structures, perhaps for reasons of defence and to display to best advantage the impressive façade. The southeastern front received special treatment in the form of a series of superimposed gypsum-plastered surfaces running along the side of the building. These are not present along the other two sides investigated so far (the south-western and north-western ones). The well-preserved condition of the plaster suggests that it may have been protected from the elements in some way, although there was no evidence for post holes or other structures that might have supported a permanent or temporary roof covering. These plaster surfaces extend for a distance of over six metres from the façade and end in what seems to be a vertical edge. Further investigation is required to determine if this is in fact the case and, if so, whether this represents the edge of a terrace or of levelling prior to the construction of the building.

\section{Private Houses}

Examination of satellite images of Tell Khaiber clearly showed one or more buildings lying some forty metres south-east of the Public Building and on the same south-west to north-east alignment. Approximately 300 square metres of the mound surface were therefore scraped in this area, and elements of three separate buildings recovered (Private Houses 1 to 3; Fig. 6). Preservation of the walls on this low-lying part of the site is generally poor, so many of the walls stood only a few centimetres high, and doorways were problematic, either because the extant walls were not above threshold height or because of subsequent rebuilding. Nevertheless, the houses provide us with a different type of context through which to appraise life at Tell Khaiber in the mid-second millennium B.C. The alignment of the houses suggests that there are two separate building phases, with Houses 1 and 2 pre-dating House 3.

House 1 is a free-standing building with four rooms, covering about fifty-three square metres. A narrow alleyway on the north-eastern side separates it from House 2. To the north-west is an open

\footnotetext{
${ }^{13}$ The British system of single-context numbering is used at Tell Khaiber. All numbers assigned to artefacts comprise a four-digit number denoting the context it was found in, followed by a number that designates that individual
}

artefact. Certain finds (selected by the SBAH) are assigned an additional identification, beginning TK1 and followed by a number. These can include more than one object. 


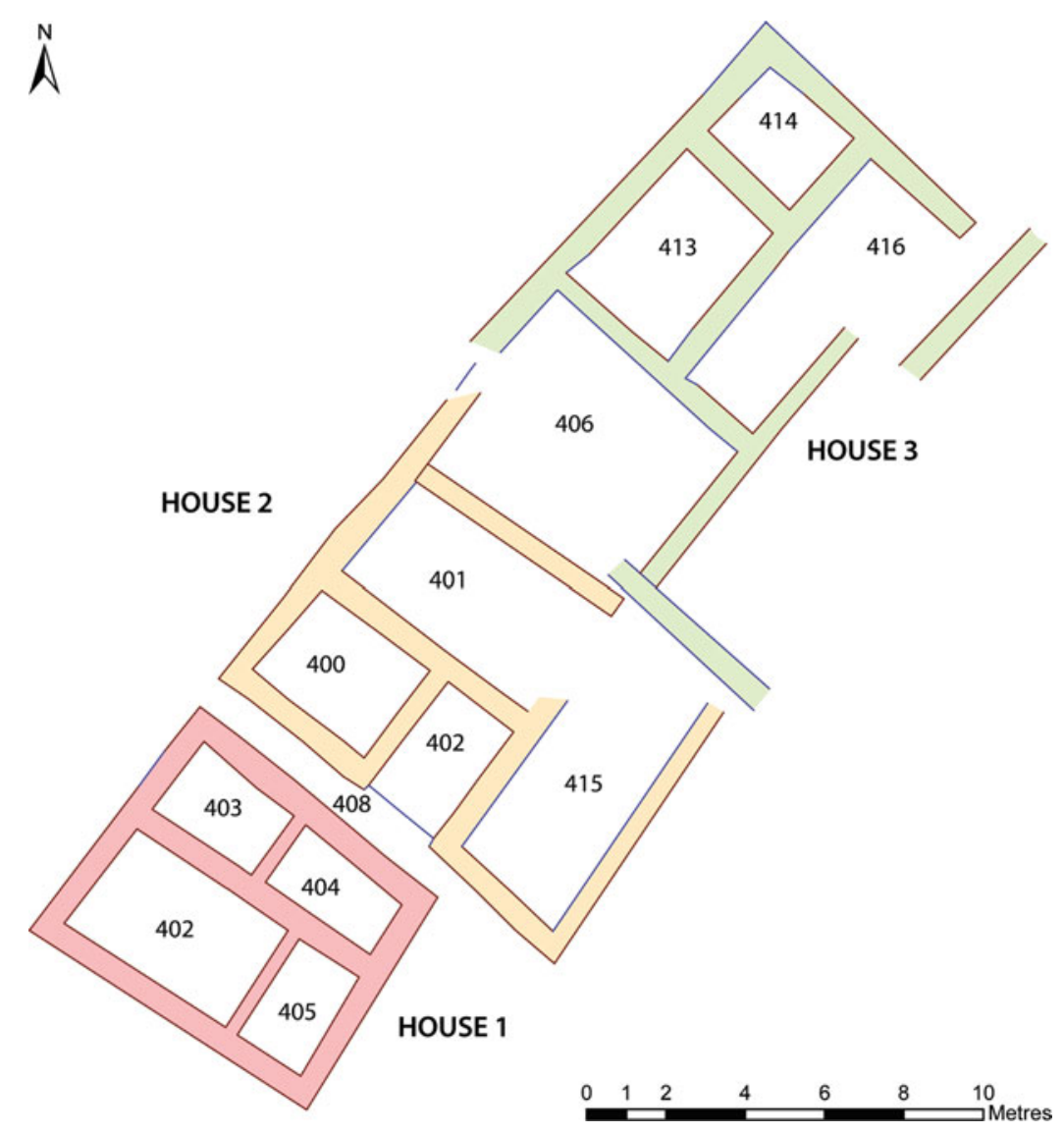

Fig. 6 Private Houses at Tell Khaiber

space, while sections of walling found close to the edge of the excavated area suggests adjacent buildings are present on the other two sides. Two rooms (Areas 403 and 412) were empty of any installations. In the south-eastern room (Area 405) there was a tannur in the eastern corner, and a freestanding bench of mud-brick in the southern part of the room. There was also a bench against the wall in Area 404.

House 2 as extant comprises three or possibly four rooms. As in House 1, the walls were not wellpreserved, standing in places less than ten centimetres high. Its relationship to House 3 to the north is also unclear. The latter was well defined only on its western edge. It has at least four rooms (Areas 406, 413,414 , and 416) which cover approximately ninety-seven square metres. Excavation was limited to one room (Area 414) so most of the plan is known only from the surface scraping.

\section{The Archive (by Eleanor Robson)}

Sixty-eight cuneiform tablets and fragments have been found to date, along with three stamped brick fragments, an inscribed figurine, and numerous anepigraphic pieces of tablet clay. Preliminary openaccess text editions, photos and glossaries of all inscribed objects are available online at http://oracc. org/urap, where comments and contributions are welcome.

The tablets. The tablets all come from three rooms in the Public Building, a few from Areas 305 and 309 , which have not yet been extensively excavated, ${ }^{14}$ but most from Area 300, which was clearly an

\footnotetext{
${ }^{14}$ From Area 305: 3006:1-2, 3006:9, 3006:17; from Area 309: 1096:24-27; from Area 300: see below.
} 
archive room. Although excavation of this area too is not yet finished, and doorways and light sources have not yet been identified, Area 300 does not seem to have had direct access to the courtyard (Area 315). It was therefore probably primarily used for the storage of tablets and tablet clay rather than for their manufacture and inscription. The room features a large round tablet recycling bin in the centre of the floor, made of clay and measuring approximately seventy-five centimetres in diameter and fifteen centimetres high. ${ }^{15}$

Although the recycling bin was empty when excavated, several small tablets and fragments were scattered around its edges, as if overlooked during the final cleaning process. ${ }^{16}$ There was another thin scatter of small fragments to the south-west of the bin, in the middle of the room. ${ }^{17}$ The remainder of the tablets were recovered in distinct clusters along the north-east and south-east walls of the room, apparently the remnants of a once well organised storage system. ${ }^{18}$ Although the majority of the tablets found in Areas 300, 305, and 309 document the administration of grain and agricultural personnel in the Akkadian language, a dozen or more, mostly from the eastern corner of Area 300, are the remnants of an elementary scribal training in Sumerian. We shall return to these tablets below. The rest are hitherto unidentified fragments.

The administrative tablets are all, in Postgate's useful terminology, "unilateral records, storing information for the internal purposes of the organisation", rather than "bilateral instruments, constituting evidence of a transaction between two parties". ${ }^{19}$ Supplementing his classification with my own categorisations of tabular accounts, we can divide them into four distinct types: ${ }^{20}$

Memoranda: ephemeral notes which informally record one or more pieces of information, usually in the form of a prose narrative but sometimes a list, with horizontal rulings dividing the sections but no headings. They are all inscribed in landscape format (i.e. parallel to the long edge of the tablet) and most are dated to the month and day, one also to the year (see further below). ${ }^{21}$

Numerical lists: in this archive, these are all two-column enumerations of workers, perhaps collated from memoranda or perhaps written as a primary document. ${ }^{22}$ They may be in portrait, landscape or round format, apparently chosen according to the length of the list. Some were originally ruled in portrait format then rotated and written along the long side, with pointed stylus holes used to fill in the blank cells on the centre of the tablet. ${ }^{23}$ Most concern small quantities of grain, specified as HAR.GAL.Ú(.MEŠ) hargallû or as ŠE(.GUR) ŠU.TI.A ENSÍ(.MEŠ) "grain received (from) the farmers (iššiakk $\bar{u})$ " in the cases where headings survive. A minority tally (usually) small numbers of unspecified commodities (or personnel) against each individual, either without formal headings or marked as ma-hi-ir "received". ${ }^{24}$ No list is totalled, and none attributed to a named scribe or functionary. A few are dated to the month and day, one also to the year. ${ }^{25}$

Tabular accounts: at Tell Khaiber, these typically tally expected quantities of incoming barley with amounts actually received, over three quantitative columns followed by the name of the worker concerned. All accounts seem to have been written in portrait format, with headings, so far as the surviving tablets suggest. In most cases, the deficit $(m u t \hat{u}(m)$, written LÁL.İ) is recorded as paid off (İ.SÁ, probably a writing for išaru(m), lit. "straight, proper"). ${ }^{26}$ As with the lists, there are no

\footnotetext{
${ }^{15}$ On tablet recycling facilities, in both domestic scribal settings and institutional buildings, see Faivre 1995; Tanret 2002: 4-8; Robson 2008: 237.

${ }^{16}$ Tablets found around the recycling bin: 3064:18, 3064:101, 3080:1-5.

${ }^{17}$ Tablets found south-west of the bin: 3064:20, 3064:26, 3064:106-8.

${ }^{18}$ Tablets found in the north corner: $3064: 12$, 3064:14-15, 3064:71-76; by the middle of the north-east wall: 3064:13, 3064:51-52, 3064:62-65, 3064:67, 3064:88-89, 3064:93-94, 3064:97-98, 3080.06; in the east corner: 3064:48-49, $3064: 53$, 3064:79, 3064:82-84, 3080:7, 3080:9-21; along the south-east wall: 3064:33, 3064:57. On storing tablets in reed baskets, quppu, see most recently Postgate 2014: 83-5.

${ }^{19}$ Postgate 2014: 414.
}

\footnotetext{
${ }^{20}$ Postgate 2014: 414-17; Robson 2004: 116.

${ }^{21}$ Memoranda: 3006:17, 3064:73, 3064:76, 3064:94, 3080:1-3, 3080:5.

${ }^{22}$ Cf. Postgate 2014: 79-80.

${ }^{23}$ 3064:67, 3064:72.

${ }^{24}$ Cf. Rositani 2011: no. 79, a numerical list of the number of harvesters provided by each of eight iššiakku-farmers, probably from about Hammurabi year 40 .

${ }^{25}$ Numerical lists: 1096:25, 3006:2, 3064:13, 3064:48-49, 3064:52-53, 3064:57, 3064:65, 3064:67, 3064:72, 3064:74, 3064:83, 3064:101, 3080:4, 3080:6.

${ }^{26}$ Correcting Dalley 2009: 225, 239, 241, 247, 249, 258, 269, 271 who reads GÚ for LÁL.İ and ni-di for İ.SÁ without translation or commentary.
} 
summations or attributions of accountability at the end of the document, though at least some (perhaps originally all?) were dated to the month and day, perhaps also to the year. ${ }^{27}$

Letters: just one short letter has been found to date, written on a landscape orientation tablet. It opens with the classic Old Babylonian greetings formula, [a]-na a-ta-na-ah-ì-[li] / qi-bi-ma / um-ma i-tam-man-kam / a-hu-ka-ma, "Speak to Atanah-ili, thus Itammankam, your brother", and tells the recipient to "let the grain move on" (ŠE.GUR le-ti-iq). It is undated. ${ }^{28}$

In addition there are several fragments of administrative documents, inscribed either with capacity measures or with personal names, which are not complete enough to identify as either numerical lists or tabular accounts but must be one or the other. ${ }^{29}$

The documents are very similar in format, content, terminology, ductus, and orthography to a subset of the Sealand Dynasty tablets published by Dalley $(2009 ; 2010) .{ }^{30}$ While that corpus does not appear to contain any memoranda, her "allocations of hargalûu-grain/flour" and "personnel lists" map onto the Tell Khaiber numerical lists, while many of her "ledgers" are similar to our tabular accounts (though on a much wider range of subjects). In particular the scribal habit of marking empty cells in a table with the pointed end of a stylus is shared by both groups of tablets. ${ }^{31}$ Further, the two legible year names in our corpus read (in Sumerian), mu a-a-dara $3^{-}$ galam-ma lugal-e "Year: Aya-dara-galama became king", as also found on five of the Schøyen tablets (Fig. 7). ${ }^{32}$

According to later cuneiform tradition Aya-dara-galama was the eighth king of the Sealand Dynasty, which conquered southern Babylonia from Samsu-iluna. ${ }^{33}$ Van Koppen's useful summary of the evidence implies that Aya-dara-galama was probably a contemporary of Samsuditana, the last king of Babylon, or Agum-kakrime, its first Kassite ruler, or perhaps his successor Burna-buriaš I. ${ }^{34}$ Depending on one's allegiance to Middle, Low-Middle, Low or Ultra-Low chronology, that dates the Tell Khaiber archive to somewhere between $c .1620$ and c. 1480 B.C.

Finally, the archive room Area 300 has so far yielded some twenty fragments of tablets bearing elementary scribal exercises (Fig. 8). ${ }^{35}$ Their discovery was a complete surprise, given that almost all known archaeologically contextualised assemblages of Old and Middle Babylonian school tablets are from urban domestic settings. ${ }^{36}$ Unlike the administrative tablets, many of which survive more or less intact, all but one of these had clearly been deliberately ripped up in antiquity ready for recycling, perhaps immediately after production. The fact that the large majority were found in the eastern corner of the archive room, slightly below the level of most of the administrative tablets, suggest that they had been emptied out of the tablet recycling bin and dumped in a corner, either prior to the laying of a new floor ${ }^{37}$ or before the stored administrative tablets collapsed on top.

One tablet carries a very basic exercise in writing the elements of cuneiform script. The eight further exercises that have been identified to date are all extracts from the thematic word list $\mathrm{Ur}_{5^{-}}$ $\mathrm{ra}$, a mainstay of elementary scribal education which underwent substantial expansion over its long history. ${ }^{38}$ The "loosely standardised" version used in eighteenth-century Nippur comprised

${ }^{27}$ Tabular accounts: 1096:26, 3064:12, 3064:15, 3064:18, 3064:26, 3064:33, 3064:51, 3064:89.

${ }^{28}$ Letter: 3064:93.

${ }^{29}$ Administrative fragments: 1096:24, 1096:27, 3006:1, 3006:9, 3064:20, 3064:62-4, 3064:71, 3064:98, 3064:107-8, $3064: 116,3080: 25$.

${ }^{30}$ However, the tablets are almost certainly not from Tell Khaiber, which shows no signs of looting. Dalley's description of the tablet fabric as "often dark-grey-black clay often heavily impregnated with salt" is also in sharp contrast to the light brown, salt-free tablet clay of the archive.

${ }^{31}$ E.g. Dalley 2009: pls. CLXXVII no. 64, CLXXIX no. 375, CLXXXI nos. 371-5, 389, 394; 3064:67, 3064:72. But note too the same feature on two unprovenanced numerical lists from the as yet unlocalised Dur-Abi-ešuh (thought to be on the edge of the Tigridian marshes), both dated to Samsu-ditana 2 (Lerberghe and Voet 2009: nos. 59, 62).

${ }^{32}$ Dalley 2009: 11 year name D; 3006:17; 3064:67.
${ }^{33}$ See Charpin 2004: $342-46,360-61$ for a detailed presentation of the evidence for Samsu-iluna's loss of control over the south, first in his 8th-11th regnal years and with further losses around his 30th.

${ }^{34}$ van Koppen 2010: 546-47, 462.

${ }^{35}$ From the northern corner of Area 300: 3064:14, 3064:97; from along the north-eastern wall: 3064:88; from the eastern corner: $3064: 79$, 3064:82, 3064:84, 3080:7, 3080:9-21; from the south-west area: 3064:106.

${ }^{36}$ For convenient overviews and references to further literature, see Robson 2008: 94 (Old Babylonian); Veldhuis 2014: 242, 281, 297 (Middle Babylonian).

${ }^{37}$ A similar deposit of fragmentary school tablets is known from Level III of the ăšipus' house (Ue XVIII/1) in late fourth-century Uruk: see Robson 2008: 227-28 and n35, 237-38.

${ }^{38}$ Writing exercise: 3064:14; $\mathrm{Ur}_{5}$-ra: 3064:82, 3064:84, 3064:88, 3080:9, 3080:13-15, 3080:19. 

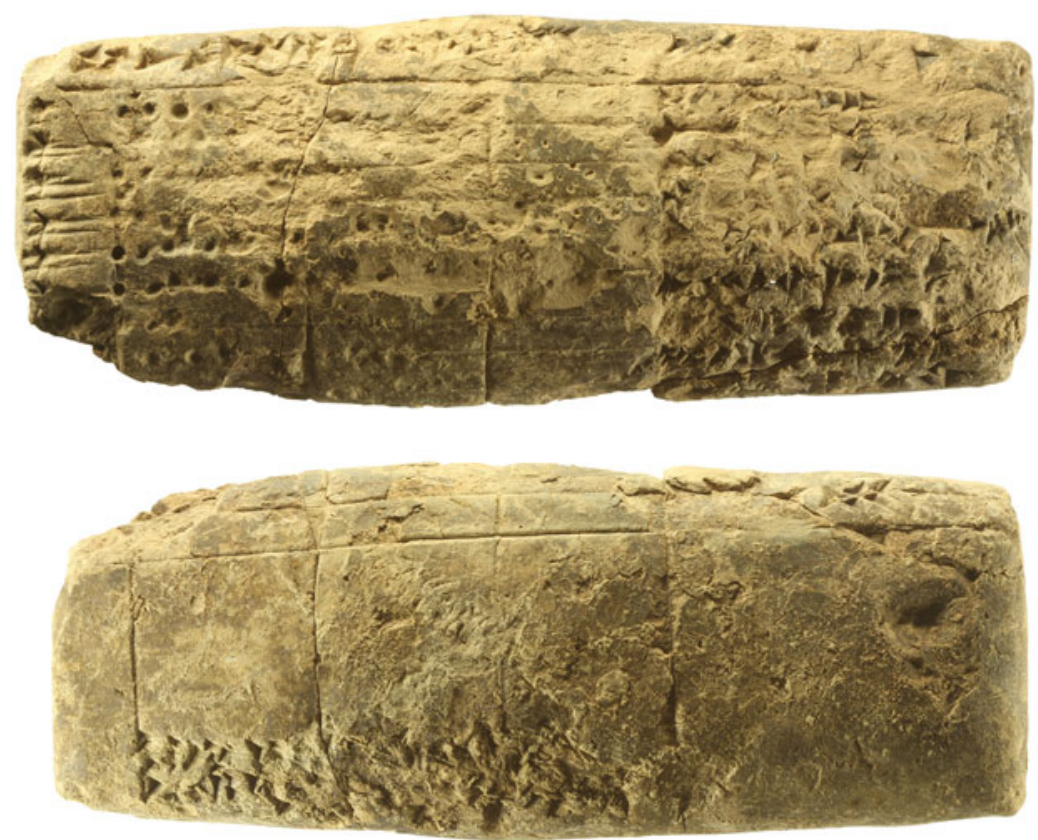

Fig. 7 Tablet listing grain receipts dating to accession year of Aya-dara-galama. 3064:67. Ht. $9.8 \times 3.4 \mathrm{~cm}$

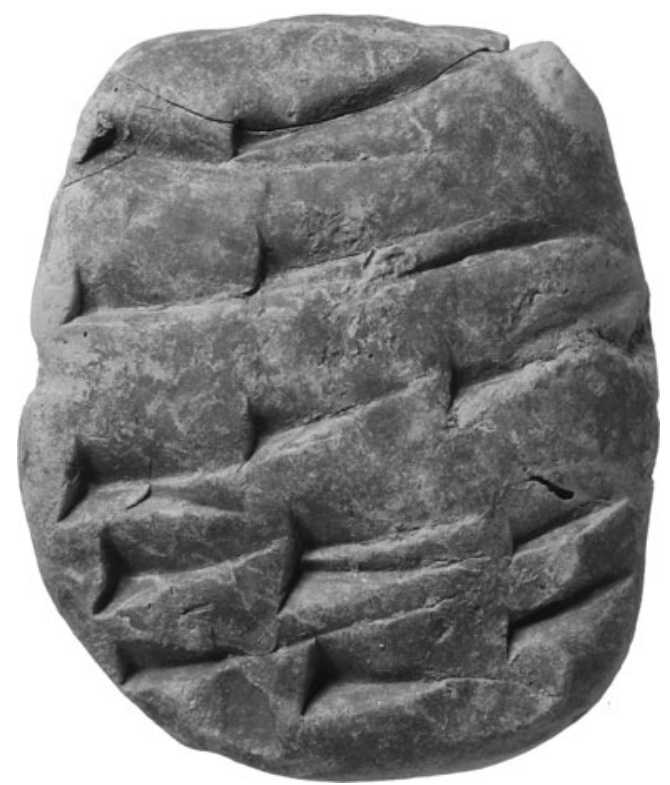

Fig. 8 Writing exercise. 3064:14. Ht. $4.5 \mathrm{~cm}$

around 3600 entries in monolingual Sumerian, formally divided into six chapters but had at least doubled in length and acquired optional Akkadian translations by Kassite times. ${ }^{39}$ The Tell Khaiber fragments not surprisingly represent an intermediate phase in the development of $\mathrm{Ur}_{5}-\mathrm{ra}$ : they are all monolingual, expand on the Old Babylonian version(s), and, like Kassite exercises, often omit the first sign of a word if it is identical to the preceding entry ${ }^{40}$ Most of the fragments

${ }^{39}$ Veldhuis 2014: 149-57, 228-29.

${ }^{40}$ Cf. Veldhuis 2014: 250-52. 
are from the chapters of $\mathrm{Ur}_{5}$-ra on metals and on stones; one is a list of wild animals and another may be from the chapter on leather objects. Together they are drawn from chapters 2-4 of the Old Babylonian Nippur version, chapters 7, 9 and 10 of the Middle Babylonian recension.

Economy and society as seen through the archive. Even from these generic descriptions it is clear that the archive represents the output of a relatively light-touch administration. When compared to agricultural documentation from other second-millennium sites, such as late Old Babylonian Sippar, Kassite Nippur, Middle Assyrian Dur-Katlimmu and Tell Sabi Abyad, its laconic nature is even more striking. ${ }^{41}$ The Tell Khaiber scribes, so far as we know, did not keep records of labour contracts (if any were ever written), ${ }^{42}$ record field sizes, monitor agricultural activity throughout the year, ${ }^{43}$ or account for seed grain, draft animals or field equipment such as ploughs or sickles. Of course, it is always possible that such documents were stored elsewhere, written on perishable media, and/or shipped elsewhere with the grain. ${ }^{44}$ However, the tablets that do survive suggest that this was a small scale, relatively unhierarchical operation in which much was left undocumented. For instance, it was not always necessary to document whether grain was being paid out or coming in, as this was also apparently self-evident. As a first approximation, it seems reasonable to assume that the lists record outgoings, which did not need to be reconciled, while the accounts show actual income tallied against expected receipts. But no credits or debits are ever totalled, or compared against one another. Likewise, there appears to be no formal apparatus of accountability on the documents, such as sealings, or the names and titles of responsible officials or institutional authorities.

The sole letter, between social equals - "brothers"-also gives this impression of an informal, transparent community. Nevertheless it is possible to detect some formal chain of command, beyond the very fact that the tablets needed to be written at all. One tablet records the names of three ÉRIN.MEŠ $\check{s} a$ sa-ar-ta $i$ - $p u$-šu, "workers who have behaved dishonestly", presumably in readiness for future punishment. ${ }^{45}$ Amongst the recipients of grain and flour are three named scribes, DUB.SAR, including Atanah-ili, the recipient of that letter. The fact that his correspondent Itammankam can give a scribe orders, and seemingly write a short letter in his own hand, suggests that he is, at least to some extent, in charge. ${ }^{46}$ At least two different men by that name are attested in the archive, often on the same tablets: a date-palm gardener (NU.GIŠ.KIRI ${ }_{6}$, three attestations), the son of Iluni (four attestations), and/or an Itammankam who is not further described (four attestations).

And then there are the ten ENSÍs, išsiakku(m)-farmers, who are clearly a profession apart. They always appear as a group, either as the subject of their own documents or listed quite separately from the other men, either on the reverse of a tablet or at least separated from them by empty lines. ${ }^{47}$ Given the laconic nature of the documentation, it is not yet possible to tell whether they are landowners paying tax, tenants paying rent, or state dependents working for rations. All three statuses have been proposed for second-millennium farmers. ${ }^{48}$ If they had any superior to whom they reported, that person is never named. Certainly, on the evidence deciphered to date, they were much less closely managed than their counterparts elsewhere.

\footnotetext{
${ }^{41}$ Rositani 2011 (late Old Babylonian Sippar); Sassmannshausen 2000: 103-9 (Kassite Nippur); Wiggermann 2000 (Middle Assyrian Tell Sabi Abyad); Postgate 2014: 313-25 (Middle Assyrian Dur-katlimmu).

${ }_{42} \mathrm{See}$, for example, the harvest contracts from (mostly late) Old Babylonian Sippar published by Rositani 2011: nos. $1-78$, which are closely contemporary with the Tell Khaiber tablets.

${ }^{43} \mathrm{An}$ accessible overview of these tasks is given by Mauer 1983.

${ }^{44} \mathrm{Cf}$. the notes in alphabetic scripts on some of the tablets published by Dalley 2009: 15-16.

${ }^{45}$ 1096:25.
}

\footnotetext{
${ }^{46}$ See http://oracc.org/urap/qpn-x-people for a current glossary of personal names from the archive. A full discussion of them will be given in a later publication.

${ }^{47}$ Tablets mentioning the farmers, by name or as a cohort: 3064:33, 3064:48-9, 3064:53, 3064:57, 3064:67, 3064:72, 3064:83, 3064:94, 3064:101, 3064:107, 3080:2.

${ }^{48}$ Cf. Rositani 2011: 28 (late Old Babylonian Sippar); Sassmannshausen 2001: 103-5 (Kassite Nippur); Wiggermann 2000: 188-90 (Middle Assyrian Tell Sabi Abyad); Postgate 2014: 313-18 (Middle Assyrian Durkatlimmu). The Assyrian term for 'farmer' is ekkāru, lúENGAR.
} 
Around 150 further individuals are named in the archive, many more than once. Some are identified by patronym, some by occupation, and others seem to require no further explanation. In some lists men are grouped by profession, and/or assigned to a $10^{-t i}$, ešertu "decury" or group of ten. ${ }^{49} \mathrm{In}$ the former case, the occupation of the first man is given and those following are described as TAB.A.NI, tappašu "his partner". In the latter case, the ten men PN1-PN10 may be identified by patronym or profession, followed by a summary line stating, "decury of PN1". The term rab ešerti, "decury leader", is not used. Professions identified so far include: ${ }^{50}$

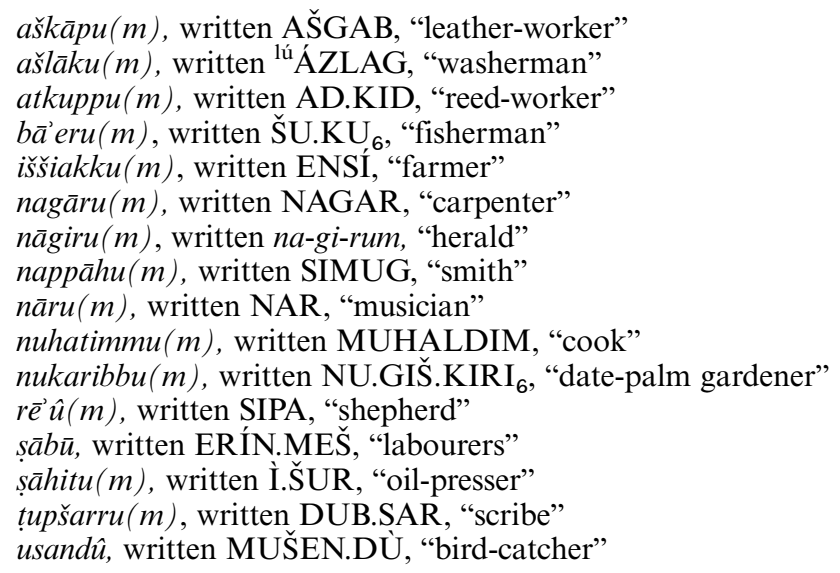

In general these titles give the impression of a dispersed, mostly rural community who are pressed into agricultural service at harvest time, whether through a formal obligation such as $i l k u(m)$-duty, moral pressure to serve the community, or the incentive of payment. We have not yet found any documentation of specialist agricultural occupations such as ploughmen or oxen-drivers, or boatmen for the transport of grain. Nor do any slaves or any women seem to have been involved.

Some of the harvest must have been stored locally, because there are two surviving accounts of ŠE LIBIR, "old barley" from a previous year. ${ }^{51}$ Ultimately, however, much of it was destined "for the palace" $a-n a$ É.GAL, as documented on at least half a dozen tablets. ${ }^{52}$

Other cuneiform items. Three fragments of baked brick bear the stamped standard short inscription of the Ur III king Amar-Suen, known from many dozens of exemplars. Pieces of baked brick occur occasionally in excavation and in surface clearance, but not in the quantities one might expect, given their relative indestructability, if a building of royal patronage were represented, and we assume for now that they may originate elsewhere.

A headless fragmentary clay figurine of a seated animal has inscribed on its flank: ${ }^{53}$

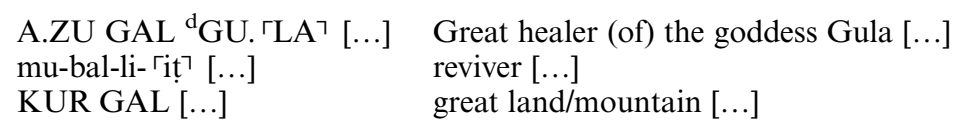

The symbol of Gula is a dog, and the figurine might be of one, although the paws, which survive, are more lion-like. It was found in surface clearance over the Public Building, and may belong to an eroded level of it.

\footnotetext{
${ }^{49}$ Professional groupings and decuries: 3064:33, 3064:49, 3064:53; professional groupings only(?):3064:48, 3064:57, 3064:107 (fragment), 3080:2 (note); decuries only(?): 3006:2 (fragment).

${ }^{50}$ See the Akkadian glossary at http://oracc.org/urap/akk$\mathrm{x}$-oldbab/ for further details.
}

\footnotetext{
${ }_{52}^{51}$ Accounts of old barley: 1096:26, 3064:51.

${ }^{52}$ Tablets mentioning deliveries "to the palace": 1096:26, 3064:63, 3064:76, 3064:89, 3064:107, 3080:2.

${ }^{53} 1005: 18$.
} 

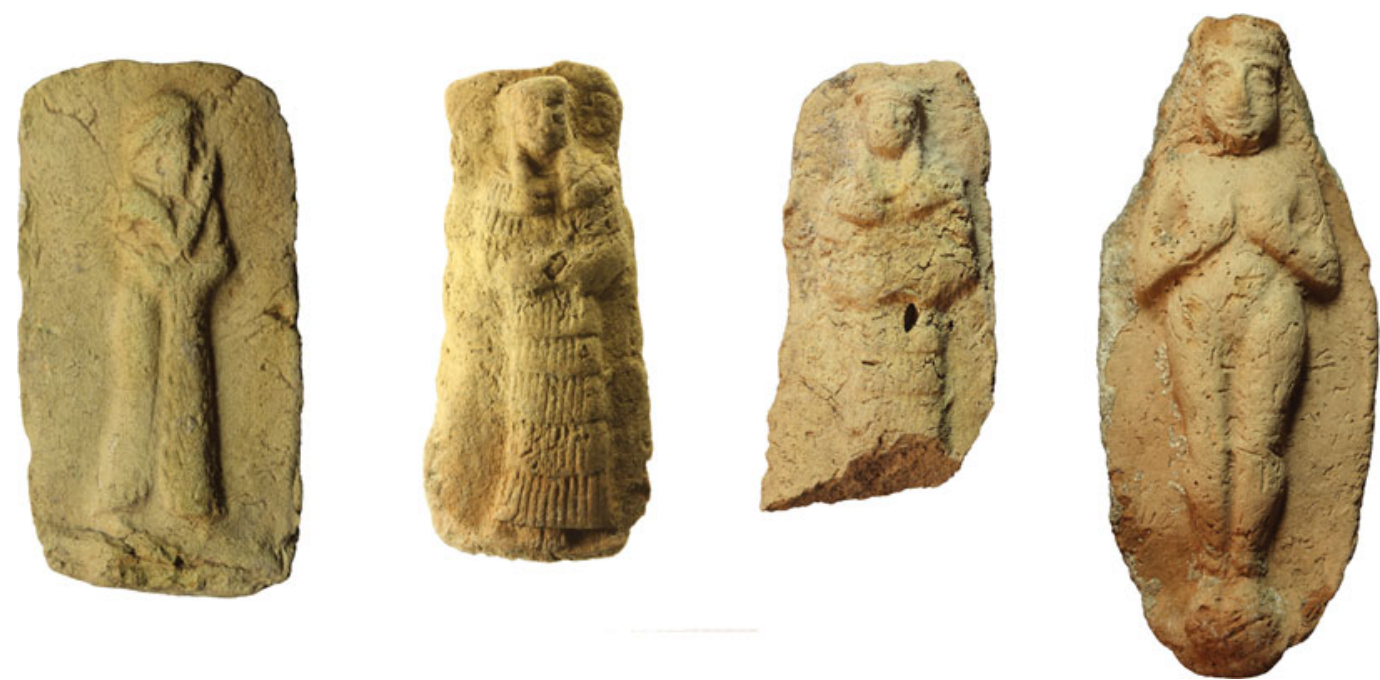

Fig. 9 Moulded plaques of lightly baked clay: a. Male worshipper. 1010:04. Ht. $9.7 \mathrm{~cm}$. Under mound surface in Area 122. b. Naked female. 3009:07. Ht. $12.2 \mathrm{~cm}$. Under mound surface, outside Area 310. c. Clothed female. 3002:1. Ext. Ht. 7.9 cm. Occupation/debris in Area 310. d. Clothed female. 1079:81. Ht. $9.0 \mathrm{~cm}$. Occupation in Area 101

\section{Artefacts}

The assemblage of objects and artefacts found in the Tell Khaiber Public Building and the nearby Private Houses conforms to that usually labelled "Old Babylonian". Dating it specifically to the time of the Sealand kings would not be possible without the chronology supplied by the tablets. Continuing excavation may allow us to pinpoint Sealand "types", and thus contribute to better dating criteria, but for now the most useful question we can ask of the material assemblage is "How does it reflect or augment what we infer from the textual information about life in and around the Public Building?"

Clay plaques are the most easily recognized "Old Babylonian" artefact type from the excavations, with eight identified so far. All depict a single human figure (Fig. 9). Of those not too worn to decipher, one is a male worshipper in a fringed cloak (Fig. 9a), one a naked female offering her breasts (Fig. 9d), and two, actually cast from the same mould, a clothed female in a flounced dress and head-dress, with clasped hands (Fig. 9b-c). There was also a broken-off female head. ${ }^{54}$ Their find spots are distributed in and around the Public Building, and they have of course been found in their place of final discard, not necessarily their place of last use.

All the plaques are made from lightly baked clay and produced from a mould. The male worshipper and the two clothed females are in relief on a rectangular background, but the others, including the fragments, have been cut away around the figure, making the whole into an elongated oval. The realization is fairly crude, the mould sometimes worn, and the clay not especially fine or wellprepared, and in this they are typical of the similar plaques that are attested from at least the Ur III to the Neo-Babylonian period, all over Mesopotamia. ${ }^{55}$ There is an extensive repertoire of themes, including animals, double figures, gods and goddesses, musicians, demon masks and erotic scenes, but all those from Tell Khaiber so far are of the single figure variety. The literature devoted to these strangely compelling little artefacts and their iconography is extensive, and they feature in studies on religion, gender and sociology. Assante, for example, sees "a direct correlation between rising plaque consumption and rising community strife", asserting that production increased after the fall of the Ur III, and because major gods caused mass destruction, "pocket gods" became more popular. "The plaque industry", she suggests, "rose in response to the people's need during a time of social crisis",

\footnotetext{
${ }^{54}$ 3064:06, from debris in Area 300, the room with most of $\quad{ }^{55}$ Moorey 2004. the tablets.
} 

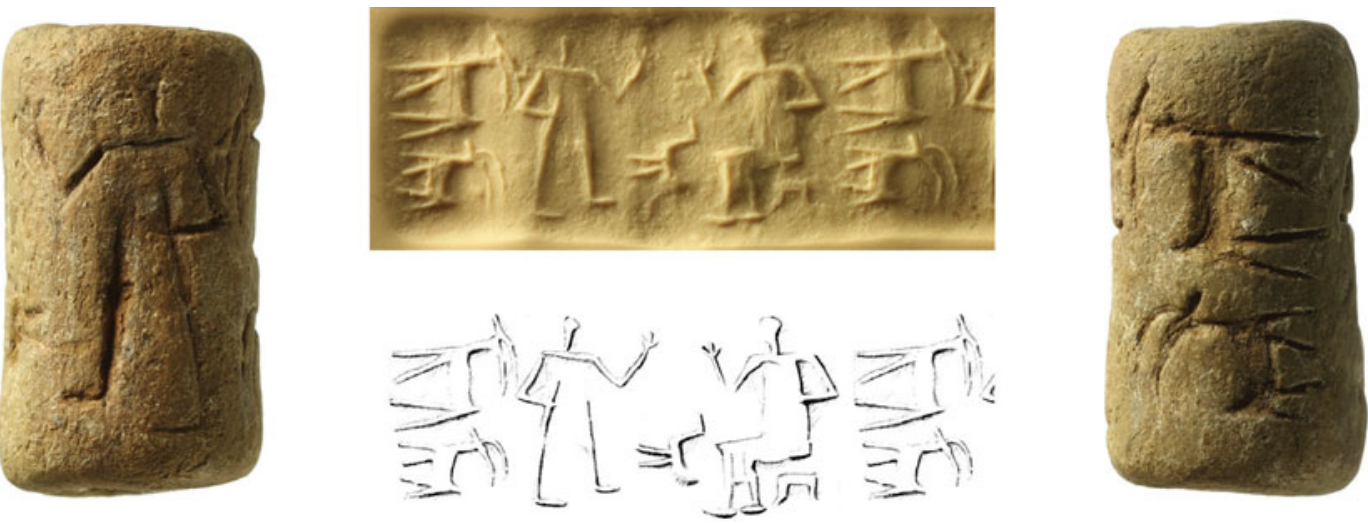

Fig. 10 Clay cylinder seal. 3025:22. Length $2.2 \mathrm{~cm}$. Occupation/debris in Area 302

and "plaques served as a unifying force in the face of social change". ${ }^{56}$ While all this goes beyond the bounds of what can be verified from archaeology, it is reasonable to assume that the very portable nature of plaques means they were most probably for some kind of personal use, and the cheap and careless manufacture suggests they were not expensive to obtain.

The male worshipper and the clothed female have close parallels at Ur, ${ }^{57}$ and, while there are many plaques with a single naked female facing front with her hands in front of her, she is generally slim, with a defined waist, hair in coils on her shoulders, and her hands clasped. ${ }^{58}$ Our more generouslybuilt lady, with flowing, plaited hairstyle and hands cupping her breasts, is not so ubiquitous. However, there is a similar one published from Larsa, albeit not closely provenanced. ${ }^{59}$

A single seal has been found (Fig. 10), and no sealings. Negative evidence should not, of course be relied upon, and clay sealings can be very hard to spot, but as most deposits are dry-sieved at Tell Khaiber, their complete absence from any of the areas sampled so far begins to suggest that this was not a hub of commerce, nor a place to which goods were sent sealed for security or identity. The seal was found in occupation/debris in Area 302. It is crudely made, of lightly baked clay, with a very rudimentary presentation scene, across which amble a flock of goats and a long-tailed bird. Studies of cylinder seals tend to deal with the attractive, often unprovenanced, beautifully carved stone examples that are so well-represented in private collections and museum holdings, but as Al-Gailani Werr has pointed out, clay seals are in fact very widely attested, especially in the Old Babylonian period, and have the same subjects and styles as their more expensive stone cousins. Poorly-drawn presentation scenes like ours, with animals in casual attendance, can be seen on clay seals from Ur, Girsu, Khafajah, Susa and Ishchali. ${ }^{60}$

Almost all the metal artefacts and fragments found at Tell Khaiber to date are, as one would expect, of copper alloy. A systematic programme of metal analysis using pXRF was carried out in 2014 and 2015, and is ongoing. ${ }^{61}$ There are generally low levels of tin in almost all copper artefacts, but at concentrations that were unlikely to give any benefit as deliberate alloys. This may suggest a lot of re-use and re-smelting of metalwork, with increasing dilution and mixing between true bronzes and pure copper. This may be consistent with Tell Khaiber being in a position quite

\footnotetext{
${ }^{56}$ Assante 2002: 20-21.

${ }^{57}$ Woolley and Mallowan 1976: pl. 71, 68 and pl. 70, 5660 , respectively.

${ }^{58}$ E.g. Hill, Jacobsen and Delougaz 1990: pl.61 b-d, from Khafajah.

${ }^{59}$ Huot 2003: fig. 18 and fig. 30:18, provenance given as "Région de Larsa".

${ }^{60}$ Al-Gailani Werr 1988: figs. 34, 48, 62, 79, 84; also pls. 1:48, II:62, III:84.

${ }^{61}$ The instruments used were a Niton XL2 GOLDD (lent by Niton UK) in 2014 and a Niton XL3t GOLDD+ in
}

2015. A set of standards, included selected standards from the CHARM set of standard metals (Heginbotham et al. 2015), was used to confirm that the metal mode of analysis of the instruments correlated highly with the reference values. This suggests that readings can, with care, be used quantitatively. However, measurements were taken on the surface of cleaned metal artefacts where there was still corrosion present. We should therefore expect values for different elements to be impacted by enrichment and leaching. 


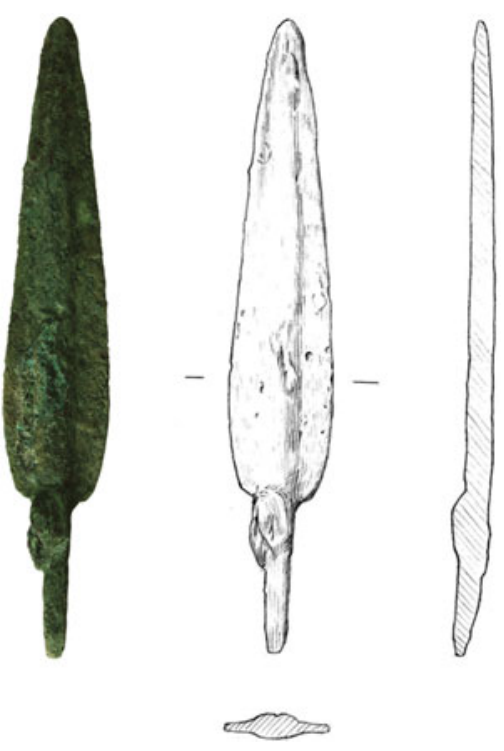

Fig. 11 Copper spearhead. 4003:10. Length $13.3 \mathrm{~cm}$. Surface clearance

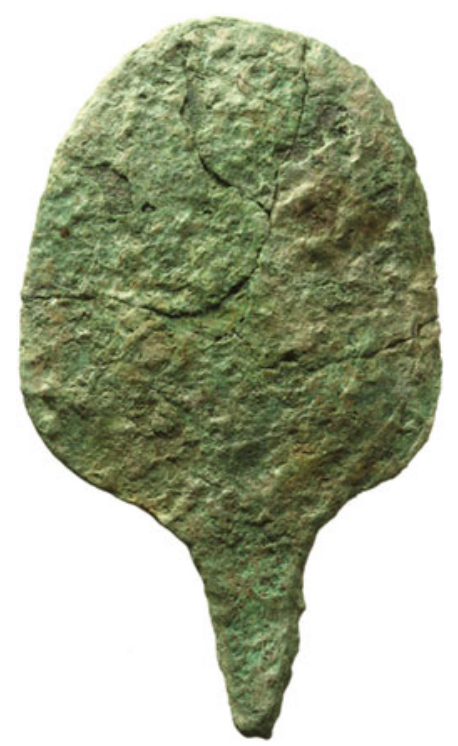

Fig. 12 Copper mirror. Length $12.0 \mathrm{~cm}$. 4006:1. Floor(?) in Area 400

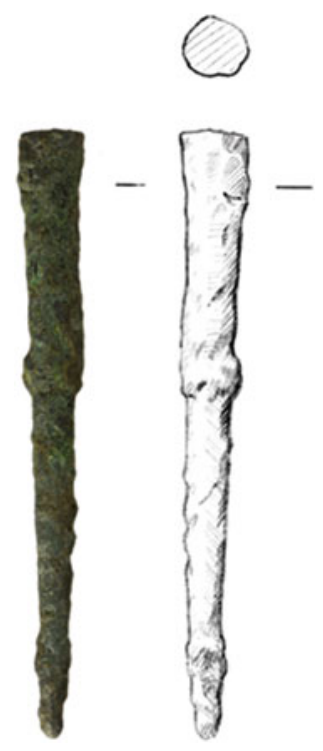

Fig. 13 Copper/silver pin. 4041:10. Length

$7.4 \mathrm{~cm}$. Grave 5, pectoral area. Area 403

far down the supply chain and reliant on re-use and recycling. Copper items also sometimes occur with patches of iron adhering to them. Whether this represents incomplete alloying (with the iron perhaps not melting fully) or composite objects is uncertain, but it does suggest some experimentation with metals.

A considerable proportion of the metal objects, especially of the relatively complete pieces, came from the area of the Private Houses. ${ }^{62}$ Among these were a spearhead and a mirror (Figs. 11 and 12), an awl or projectile, a chisel-like implement, and a bar with a loop on one end. ${ }^{63}$ Another spearhead was found in Area 301 in the Public Building, ${ }^{64}$ and a complete spatula in Area 302. ${ }^{65}$ The spearhead is obviously a weapon, and the mirror, equally obviously, is not, but otherwise it is hard to determine whether some of the implements were intended for craft activities or violent ones. The fragments included pieces of wire, pieces of pins, rods and bars, sometimes with pointed ends, and scraps of copper sheet. All these indicate a working environment, of tools and fittings, perhaps elements of harness and fishing equipment. None of them were certainly used for decoration alone. A circlet of wire found in debris inside a tannur could have been a bangle or anklet, ${ }^{66}$ and a split ring could have been an ear ring, ${ }^{67}$ but otherwise, apart from the mirror, there is remarkably little evidence for any self-adornment by means of anything made of copper.

A woman buried in a double pot grave ${ }^{68}$ was wearing a modest amount of jewellery, including two thick pins found in the pectoral area (Fig. 13). ${ }^{69}$ These are made from an alloy of silver and copper. Lead was used for implements or possibly ornaments as well, as evidenced by four lead pins or rods, three of them again from the Private Houses. ${ }^{70}$ The woman in the grave also wore a necklace of forty-eight beads of various stones: agate, carnelian, turquoise and lapis lazuli. ${ }^{71}$ The necklace

\footnotetext{
${ }^{62}$ Twenty copper artefacts or recognizable pieces thereof came from the Private Houses, out of fifty-four recorded from the excavation, excluding completely unidentifiable fragments.

${ }_{53}^{3} 4034: 3,4022: 1$ and 4003:8.

$643039: 4$, close to the mound surface, but probably associated with a high plaster floor.

65 3025:23

${ }^{66}$ 2009:02.
}

${ }^{67}$ 1094:19.

${ }^{68}$ Grave 5, in the north corner of House 1, aligned with the walls but cut from about the present mound surface. Other graves found to date have little content, and are not considered here.

69 4041:10 and 4041:11.

${ }^{70}$ 4010:01, 4065:01, 4074:01, and 3002:12.

${ }^{71}$ TK1 133 (multiple individual find numbers). 
had clearly been well-used, as there were many chips and much wear to the stones. The lapis is of poor quality and the turquoise and carnelian beads of indifferent workmanship, though the agate beads are finer. This does not point immediately to a lively trade with regions producing semi-precious stones. While we have to guess a little at the woman's social status, she was at least important enough for an intramural burial in a good-sized house, in a neighbourhood wealthy enough that the use of substantial copper implements was not a rarity.

There are many implements made from stone: querns, grinders, pounders, rubbers, tools of multiple or unknown purpose, door-sockets and vessels (Fig. 14). ${ }^{72}$ In fact, items fashioned from stone are the most numerous found, apart from pottery, which is perhaps a little unexpected in a landscape that is so poor in stone. Our finds have not yet been examined by a geologist, but many of the coarser items are of a limestone similar to that occurring not far away, in the vicinities of Eridu and Samawa, and the colourful conglomerate beachrock used for some of the querns was probably relatively local as well, from the former shore of the Gulf. Other artefacts, however, appear to be of igneous or other types of stone, which must represent imports.

All except one of the vessels is fragmentary, and may well be residual from earlier levels. The one complete one was found very near the mound-surface, but probably derives from Area 616 (Fig. 15). The soft, green close-grained stone is fairly typical for Tell Khaiber, and is sometimes also flaked and re-touched to make tools, for which it cannot have been well suited (e.g. notched tool 4074:03 below). An ancient chip to the rim of the bowl has been smoothed down. Other stone bowl fragments showed evidence of repair too, a practice consistent with a scarcity of good stone, and debris in Area 310 included a group of alabaster artefacts that look as though they may be gaming pieces in the process of conversion from fragments of a vessel (Fig. 16).

As the texts mention grain and farmers, and occasionally flour, evidence for processing might be expected. There are certainly plenty of pieces of grinders and querns, but so far none definitely associated with a processing area. Two halves of a large quern, presumably discarded, were found in Area $124,{ }^{73}$ but most of the pieces are, inevitably for this stage of the excavation, associated with deposits near the surface, and we need results from our micromorphology samples and the processing of floated samples to say anything more satisfactory about where grain was treated on site, whether it was being ground into flour or crushed for malting or both, and whether this was on a large or a purely domestic scale.

The familiar notched flint blades that are elements of composite sickles were not uncommon: twenty-six examples to date, though of course being so durable, they may not all be of second millennium date.

What were all the stone tools for? Several professions or occupations are mentioned in the texts, and while this does not mean they were being followed at the settlement itself, we do have physical corroboration for the work of the farmers (flint sickles, querns and grinders), the smith (metal implements), the cook (cooking pots and fire installations), and also the reed-cutter, if, as can be reasonably assumed, he used flint sickles and a boat. Perhaps the leather-workers and oil-pressers were among those who made use of stones with ends now pitted from pounding and their flat surfaces worn smooth from rubbing, as well as some of the other, smaller stone pieces that are enigmatic in shape but have clear traces of wear.

Bird, sheep and fish bones reinforce the presence of bird-catchers, shepherds and fishermen. Impressions of palm-leaf matting in dried clay and in the many fragments of bitumen encountered are already evidence of palm-gardening, even before we have specialist results from the botanical samples. For traditional female pursuits we are limited to four spindle whorls and five bone needles (Fig. 17), which might just as well have been for leather working. Potsherds were sometimes used as tools too, the most common type being roughly shaped pierced discs, often interpreted as net-sinkers, of which about fifty were found in Area 601, perhaps representing all that was left of a net: a further trace of the fishermen.

\footnotetext{
${ }^{72}$ Over 300 items to date, in addition to unidentifiable fragments. All stone, including fragments, was kept.

${ }^{73}$ 1022:05 and 1094:01.
} 

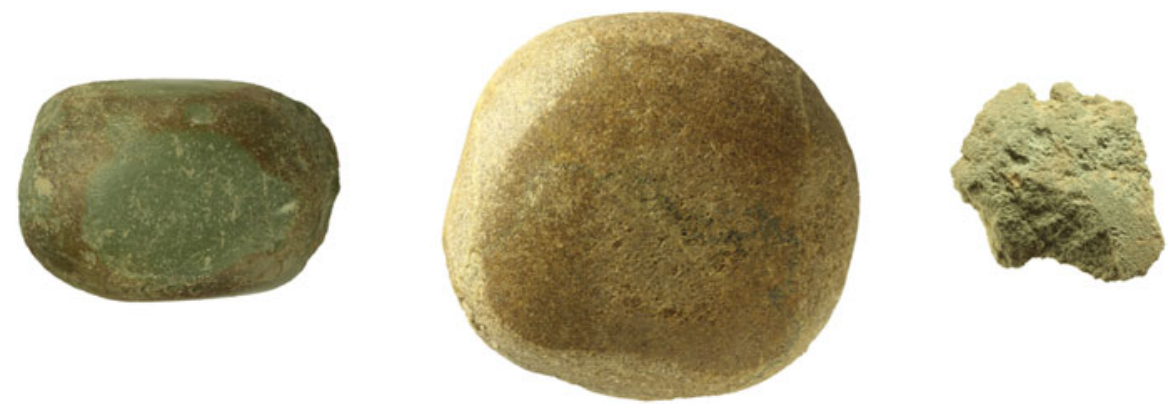

Fig. 14 Stone tools. a. Rubbing tool, of close-grained green stone. Length $5.2 \mathrm{~cm}$. 6059:09. Surface in Area

600. b. Rubbing/pounding tool, of close-grained brown stone. Ht. $6.6 \mathrm{~cm}$. 1077:06. Mud-brick collapse in Area 101. c. Notched tool, of soft green stone, perhaps for shaping or straightening. Length $3.6 \mathrm{~cm}$. 4074:03. Debris in Area 402
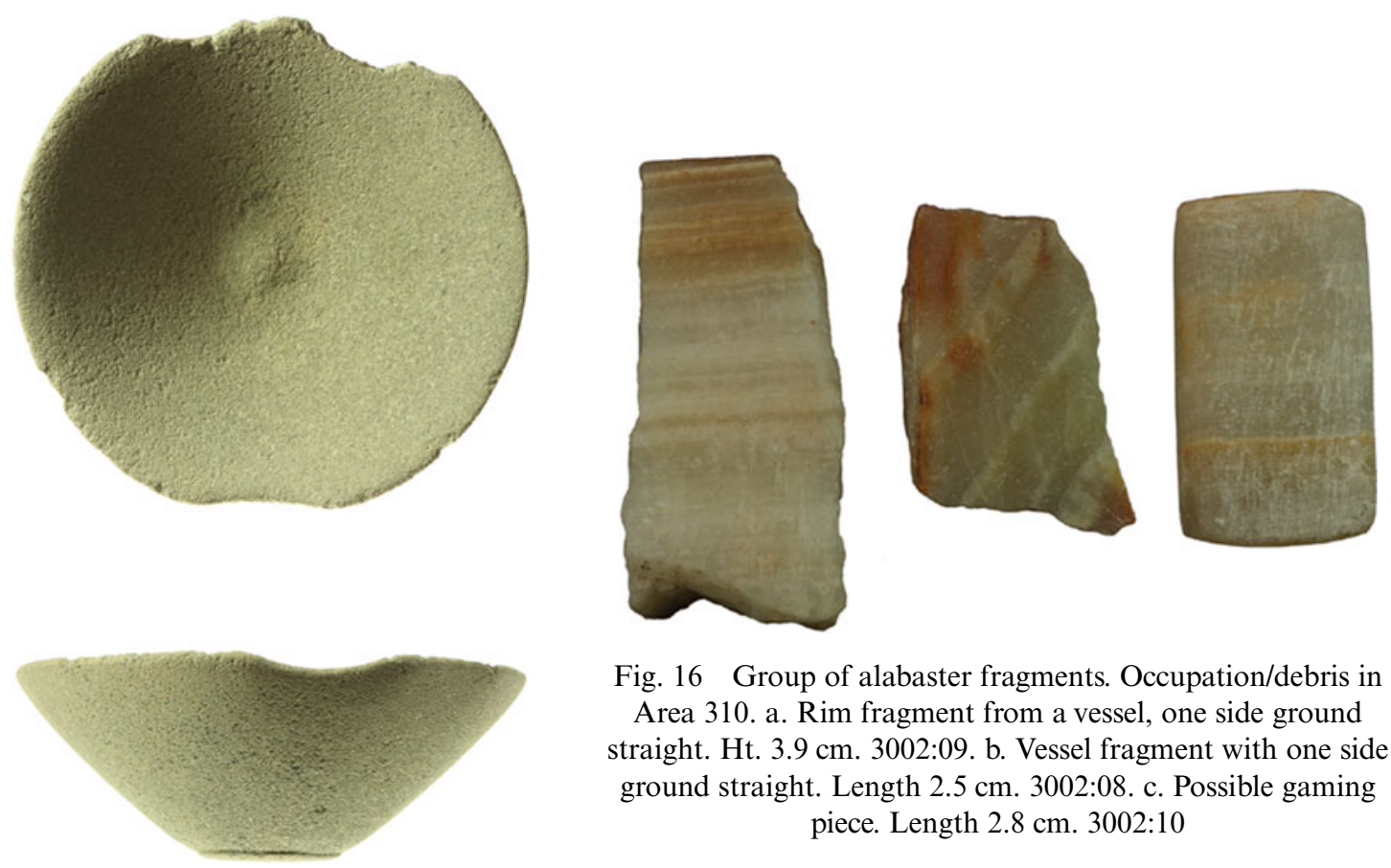

Fig. 16 Group of alabaster fragments. Occupation/debris in Area 310. a. Rim fragment from a vessel, one side ground straight. Ht. 3.9 cm. 3002:09. b. Vessel fragment with one side ground straight. Length $2.5 \mathrm{~cm} .3002: 08$. c. Possible gaming piece. Length $2.8 \mathrm{~cm} .3002: 10$

Fig. 15 Stone bowl. Ht. $4.4 \mathrm{~cm} .6064: 01$. Occupation in Area 616

Evidence for glass and glass compounds comes in the form of a composite "eye-stone" of a brown, glass-like substance, with the white part made of paste or faience, and of fragments of a possible second one, white with a deep ultramarine centre: both were found in debris in Area 101 (Fig. 18). Eye-stones have been the subject of a special study by Tim Clayden, who concludes that "they were decorative items and served neither as apotropaic objects nor as eye-inlays" (for statues). ${ }^{74}$ Eye-stones are usually made from some form of chalcedony, such as agate or onyx, some are pierced, and some inscribed. Ones made of faience are known from the middle of the second millennium onwards, and there is a close parallel for our more complete one, which shows evidence of piercing, but is not inscribed, from Haradum..$^{75}$ They have a long currency (Ur III to Achaemenid periods), but are most common in the Kassite period and most at home in Babylonia. 


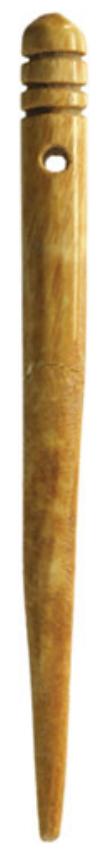

Fig. 17 Bone pin. Length $6.6 \mathrm{~cm}$. 3085:45. Mud-brick collapse in Area 304
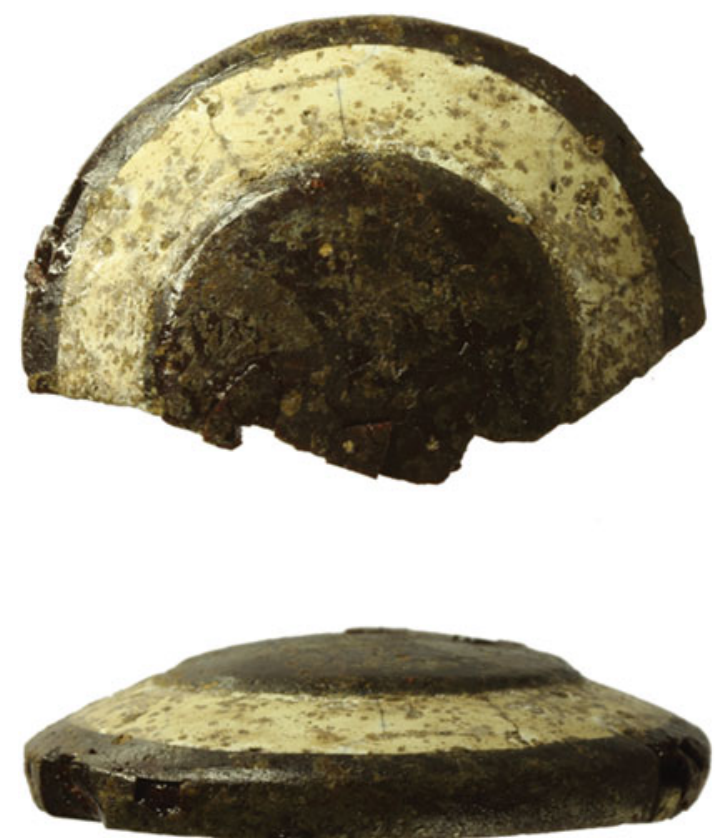

Fig. 18 Eyestone. Glass, with white paste. Max. ext. diam. $3.1 \mathrm{~cm} .1073: 17$. Occupation/debris in Area 101

\section{Pottery (by Daniel Calderbank)}

The second millennium pottery from Tell Khaiber is the subject of an ongoing comprehensive study, and the objective of this interim report is to note the main characteristics observed so far. ${ }^{76}$ Exhaustive description and illustration of all the types is beyond the scope of the present contribution, but in summary the assemblage can be grouped into fourteen distinct vessel categories, found in two principal colours, and four ware types. There are in addition unique forms, and ambiguous rim and base sherds (18.7 percent of the data set) that cannot be further categorised. Colours correspond broadly to firing temperature: pink/buff (low-normally fired) and green (high-fired), vessels being routinely fired under fully oxidising conditions. Tempers are heavy chaff, a mixture of chaff and grit, gritty, and heavy mineral inclusions. Only with cooking wares is the deliberate addition of large grits, and sometimes grog, explicit. Almost none of the Tell Khaiber pottery could be considered fine ware and deliberate surface treatment or decoration is notable by its absence. As to manufacturing technique, many smaller vessels, especially bowls and cups, were evidently thrown or shaped on the wheel (to judge from the rilling and the angles of inclusions). However, examination of X-Rays also demonstrates that some cups were in fact hand built. Larger jars and pithoi were coil built, with parts perhaps shaped with the assistance of the wheel..$^{77}$ While possible kilns on the mound are still to be investigated, production is assumed to be local. Wasters are not uncommon (c. 2.7 percent of the diagnostic assemblage) and the packed surface of a passageway (Area 110) connecting a row of rooms (Areas 100-107) was especially rich in them (c. 8.8 percent of diagnostics), suggesting that a nearby kiln dump may have been accessed for the packing material.

\footnotetext{
${ }^{76}$ Every piece of pottery recorded is denoted by a unique "pottery number", formed of the context number, preceded by "p" and followed by a number individual to that piece, e.g. p3088-138. Those that are also included in the object catalogue (more complete pieces, not for discard) have one or more additional designations (see footnote 13). For clarity, only the pottery numbers are given in this report.
}

\footnotetext{
${ }^{77}$ Courty and Roux (1995) have challenged the binary opposition between purely wheel thrown and purely handmade vessles. There is in fact demonstrable overlap and nuance in forming techniques. See also Roux and Courty (1998).
} 

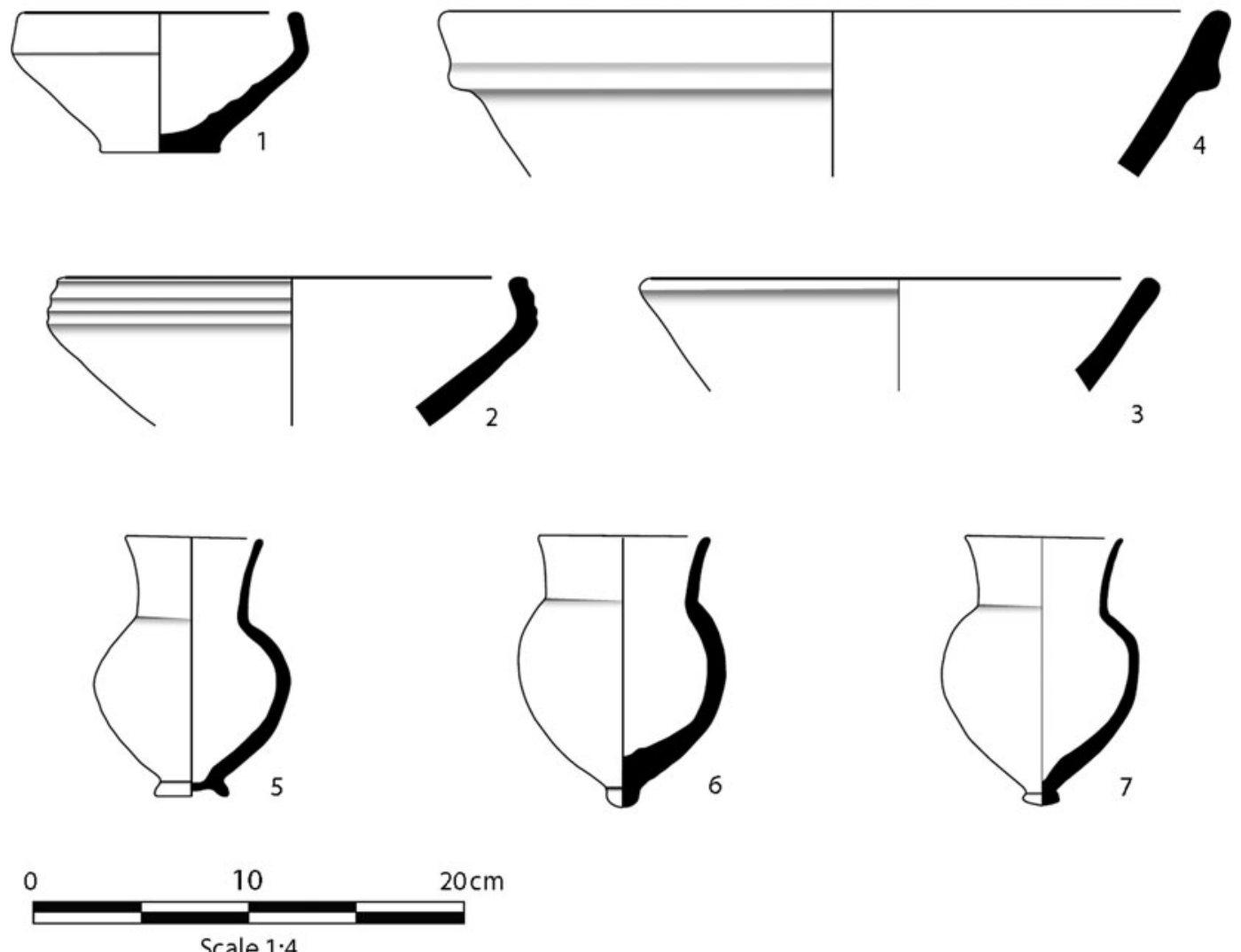

Scale 1:4

Fig. 19 1. p3088-138 Small bowl, restricted rim. White-cream int./ext. Pale pink fabric. Very few inclusions at x60. Ht. $15.3 \mathrm{~cm}$. Rim diam. $13 \mathrm{~cm}$. Base diam. $5.5 \mathrm{~cm}$. 2. p1096-307 Medium bowl, restricted rim. Cream-yellow int./ ext. Cream-grey fabric. Heavy chaff. Rim diam. 23 cm. 3. p1096-29 Medium bowl, everted rim. Yellow-buff int./ext. Brown fabric. Gritty. Rim diam. 2.4 cm. 4. p1091-165 Medium bowl, everted rim. Pink int./ext. Pink-orange fabric. Gritty. Rim diam. 3.4 cm. 5. p4021-12 Cup, flaring ring base. Cream-buff int./ext. Pale orange fabric. Light chaff/ grit. Ht. $12.2 \mathrm{~cm}$. Rim diam. $6.5 \mathrm{~cm}$. Base diam. 3.5 cm. 6. p1085-17 Cup, nipple base. Pale pink-white ext. Pale pink fabric. Light chaff/grit. Ht. 12.7 cm. Rim diam. 8 cm. Base diam. 1.5 cm. 7. p3054-397 Cup, button base. Yellowgreen ext. Cream fabric. Gritty. Ht. $12.6 \mathrm{~cm}$. Rim diam. $7.5 \mathrm{~cm}$. Base diam. $1.5 \mathrm{~cm}$

Bowls, constituting 39.1 percent of the assemblage, are the most common vessel shape found at Tell Khaiber, and fall into three main categories: small, usually with restricted rims (rim diameter $c .18$ centimetres; Fig. 19.1), medium-large with restricted rims (rim diameter c. 24-26 centimetres; Fig. 19.2), and medium-large with everted rims, which have a much wider range of diameters (Fig. 19.3-4). The next most common type is a cup, making up 12.3 percent of the entire assemblage, and the category most frequently found in a complete or near-complete state. While the overall shape is fairly much the same, the bases vary from a simple point, through nipple and button styles, to pedestals and small flaring rings (Fig. 19.5-7). Only those from the latter end of this spectrum are able to stand unsupported, and even they are not stable. The other shapes are: jars (15.5 percent); pithoi (3.8 percent); vases ( 2.8 percent); hole-mouthed cooking pots (2.4 percent); beakers (1.8 percent); stands (1.7 percent); large open vessels $(0.8$ percent $)$; trays/platters ( 0.3 percent), bottles ( 0.1 percent); and goblets $(0.05$ percent $)$.

Jars, where preserved sufficiently to distinguish the body shape, are invariably globular or torpedoshaped in profile, with rounded base, and thickened rim band. The only difference between jar types is the shape of the rim band, with rim diameters almost invariably between 10 and 20 centimetres, peaking between 14-18 centimetres, regardless of rim shape (Fig. 20.1-3). Cooking pots seem to come in two distinct sizes, those with rim diameters between 10-20 centimetres and those with rim 


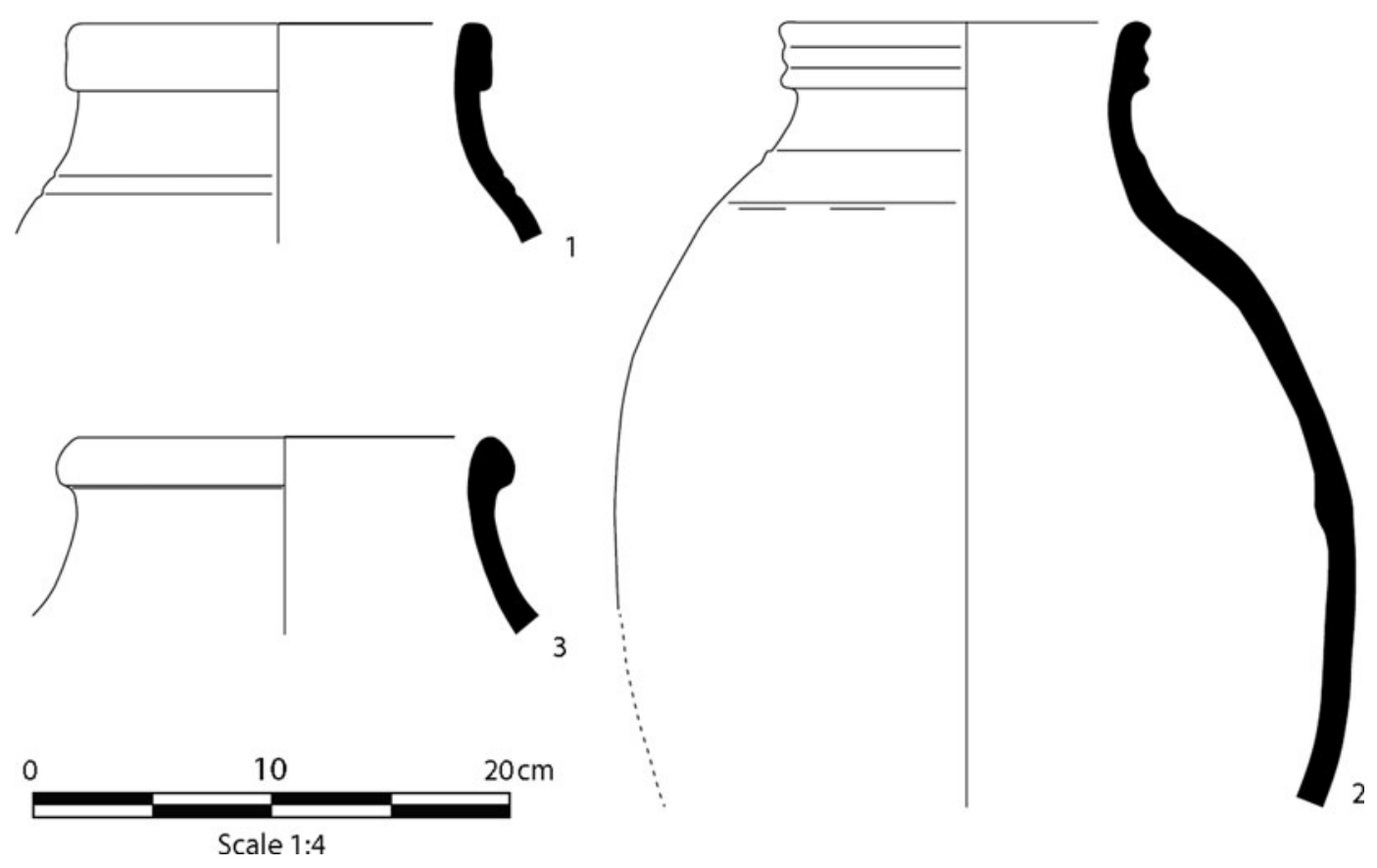

Fig. 20 1. p3025-25 Jar, thickened rim band. Yellow-brown int./ext. Green-yellow fabric. Heavy chaff. Ext. ht. $33 \mathrm{~cm}$. Rim diam. $18 \mathrm{~cm}$. 2. p3064-565 Jar, thickened rim band with multiple grooves. Pale green ext. with voids. Pale green-grey fabric. Light chaff/grit. Ext. ht. 33 cm. Rim diam. 15.5 cm. 3. p4003-17 Jar, thickened, rounded rim band. Pale green int./ext. Pale brown fabric. Heavy chaff. Rim diam. $19 \mathrm{~cm}$

diameters between 20-30 centimetres, and are markedly distinct from the rest of the assemblage, not just by their hole-mouthed shape, but from the heavy concentration of the large, angular mineral inclusions needed to improve thermal shock absorption. Cylindrical pot-stands come in two standard sizes too, one with an average diameter of 10.2 centimetres (Fig. 21.1), presumably for holding cups, and one with average diameter 22.2 centimetres, which would be more useful for supporting jars.

This is self-evidently an assemblage of utilitarian vessels, designed for everyday use rather than for decoration or show. The potters of Tell Khaiber clearly aimed for distinct standardisation of size and form. This accords with the business-like environment reflected by the texts and other artefacts.

Assessing the place of the Tell Khaiber assemblage in a regional and developmental context is hindered by the scarcity of well-recorded excavated pottery from the same region. Comparable material from $\mathrm{Ur}$ is published as illustrations that are too stylised to be useful here. Nevertheless, comparison with well recorded Old Babylonian assemblages from North and Central Babylonia studied more recently, such as those of Tell ed-Der and Nippur, makes it clear that the Tell Khaiber pottery is essentially Old Babylonian in character, whilst lacking some types characteristic of the earlier end of this period. ${ }^{78}$ Ongoing chronological examination of the ceramics will include determining whether the same dating indicators obtained further north also exist in the south, for instance the general change in the way vessel bases were finished between the Old Babylonian and Kassite periods. ${ }^{79}$ The closest contemporary assemblages from a

\footnotetext{
${ }^{78}$ For examples, see the typical elongated goblets (Gasche et al. 1998: pl. 1; Armstrong and Gasche 2014: pls. 57-62), or larger, painted vessels (van Ess 2014: 356-63 and pls. 5-8).

${ }^{79}$ To prevent cracking of during drying and firing, extra, coarser clay was added to bases. The Old Babylonian
}

practice of plugging a hole left in the base after the vessel had been formed was, in the early Kassite period, replaced by the adding of clay to the base during throwing (filled-in). See van As and Jacobs 1992; Gasche et al. 1998; Armstrong and Gasche 2014. 


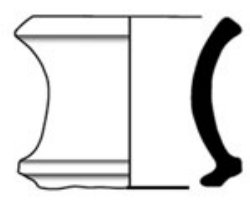

1
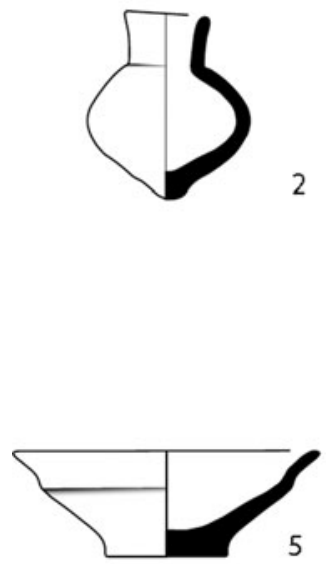

0 10
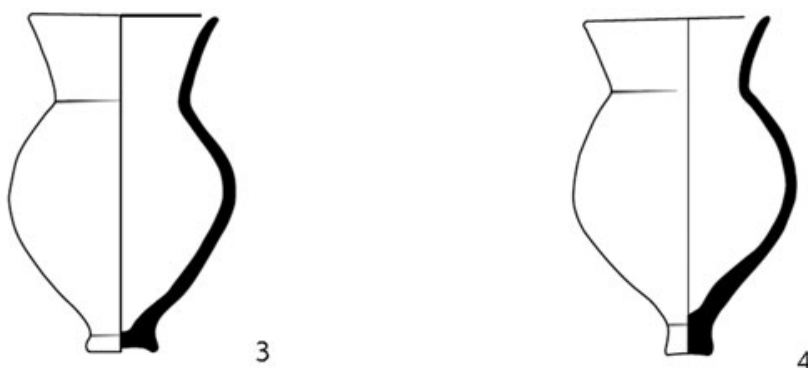

4
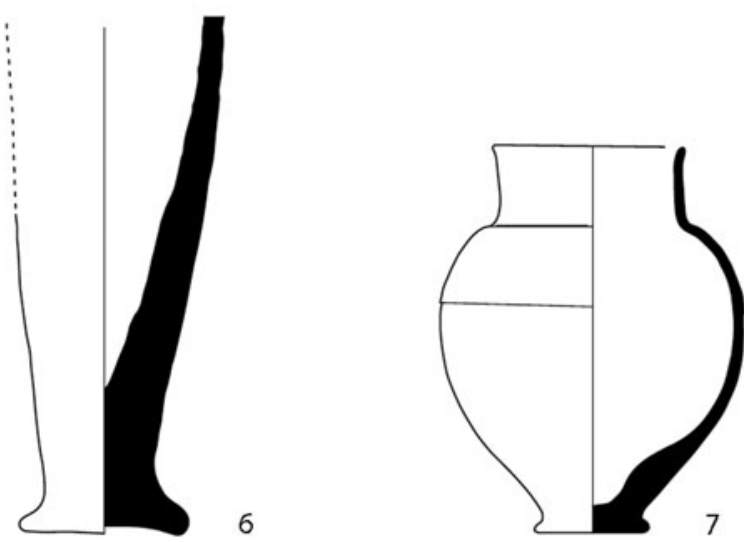

Scale 1:4

Fig. 21 1. p3054-49 Small, cylindrical pot stand. Pale green int./ext. Pale green-brown fabric. Light chaff/grit. Ht. 7.2 cm. Rim diam. 9.0 cm. Base. Diam. 9.0 cm. 2. p4021-14 Small, round-based bottle. Cream-buff ext. Pink fabric. Heavy chaff. Ht. 7.8 cm. Rim diam. 3.5 cm. 3. p4006-2 Cup, elongated body, funnel neck. Pale pink-buff ext. Pink fabric. Light chaff/grit. Ht. 14.0 cm. Rim diam. 8.0 cm. Base diam. 3.0 cm. 4. p4084-1 Cup, elongated body, funnel neck. Green ext. Green-yellow fabric. Light chaff/grit. Ht. $14.0 \mathrm{~cm}$. Rim diam. $7.5 \mathrm{~cm}$. Base diam. 2.0 cm. 5. p6088-14 Small, wavy-sided bowl. Green-brown int./ext. Pink fabric. Light chaff/grit. Ht. 4.4 cm. Rim diam. $13.4 \mathrm{~cm}$. Base diam. $5.0 \mathrm{~cm}$. 6. p0-1 Steep-sided goblet. Green int./ext. Green-grey fabric. Heavy chaff. Ext. ht. 21.4 cm. Base diam. $7.0 \mathrm{~cm}$. 7. p4041-1 Vase, platformed base. Pale green-buff ext. Light chaff/grit. Ht. $16.0 \mathrm{~cm}$. Rim diam. $8.0 \mathrm{~cm}$. Base diam. $4.5 \mathrm{~cm}$

typological point of view are those from Levels IVb-II at Tell Yelkhi, in the Hamrin Basin, ${ }^{80}$ as well as a small collection of material recently published from Uruk. ${ }^{81}$

It is too soon to make a definitive assessment of internal variation within the settlement, but a few differences have already been noted between the Public Building and the area of the Private Houses. In the latter there are far fewer bowls (down to 21.8 percent), more vases and cups (21.7 percent between them, as opposed to 15.1 percent), and almost no cooking wares. This might suggest that whatever cooking and eating took place here, it was not on a large scale. Instead, it is perhaps tempting to envisage small family groups sitting around a meal placed on a central woven mat, in the traditional Iraqi manner. The greater frequency of vases and cups, on the other hand, points to short-term storage and frequent small-scale consumption of liquids. The presence of a small bottle in House 1 also suggests the retention of more valuable liquid goods (Fig. 21.2). 
Regarding styles of individual forms, there are some indications that the excavated levels of the Private Houses may be slightly later than the topmost intact levels of the Public Building. The percentage of cups and vases with flaring bases goes up to 16.7 percent in the Private Houses, compared with 4.6 percent over the entire assemblage, and ones with unstable bases are rare altogether. Of course this need not be a chronological change, but the rarity of unstable cup basesand they are very durable - is also noted in the topsoil deposits removed from above the Public Building, presumably from the deflated level just above it. Other forms reinforce this impression, such as two of the cups from House 2 (Fig. 21.3-4), which have slightly elongated bodies and funnel shaped necks that compare well with a selection from Levels II-I (c. 1550-1300 B.C.) at Tell Yelkhi, ${ }^{82}$ and represent our best evidence for the Trichterhalsbecherflaschen dated at Babylon to $c$. 1600-1450 B.c. ${ }^{83}$ The steep-sided goblets and wavy-sided bowls characteristic of the Kassite period are only found at Tell Khaiber in topsoil deposits, and even then very rarely (Figs. 21.5-6). ${ }^{84}$ Nevertheless, the burial in House 1, cut from above the surviving surface, contains a vase almost identically paralleled in Kassite vessels from Nippur (Fig. 21.7). ${ }^{85}$

\section{Conclusions}

The fortified Public Building at Tell Khaiber provides new evidence for understanding the nature of southern provincial administration during the period between the collapse of Old Babylonian rule and political regeneration under the Kassite kings. It shows us that there was order and authority, a well-oiled system for collecting and redistributing cereal products, and that some of this was destined for a "palace". Where the palace was, who it belonged to, and whether it represented a particular building or a more abstract institution it is too soon to say. However, it is highly likely, on current evidence, that it was related to the Sealand Dynasty and may well refer to a palace (if not the main royal residence) in nearby Larsa or Ur. Among known cities, Ur would be an obvious candidate for a regional centre in the first half of the second millennium B.C., and Larsa is only a little further away. There may be other possible locations among the many, many sites in the area still to be investigated. ${ }^{86}$

Wright noted very extensive settlement in the Ur-Eridu survey during the first half of the second millennium B.C., when Ur covered at least sixty hectares and there was a widespread rural population too, recorded at fifty-seven small to medium sized sites (Wright 1981: 330). There was extensive abandonment in this area between this time and the Kassite period, when there was a resumption of royal monumental building at Ur, and regeneration in the countryside, although this may not have been extensive in the area between the two main channels of the Euphrates (Wright 1981: 331-2). The survey evidence is compatible with the known political events, i.e. the rebellion of the southern cities under Samsu-iluna, his suppression of it, and the widely-accepted view that the far south of Babylonia was de-urbanised, if not depopulated, for a period following that ${ }^{87}$ However, the limitations of survey, however well-conducted, and particularly the subtleties of southern second-millennium pottery styles in a survey context make precise chrono-historical correlations hazardous. A scenario of state collapse and its consequences does not seem entirely pertinent to our situation. The Public Building at Tell Khaiber is not a rebuild of an abandoned or ruined predecessor, but a new foundation on a very ancient tell, and the reference to Aya-dara-galama in the texts means its prime use occurred when the effective secession of the area from Babylonian control was already generations past. The references in our archive to a palace, requiring grain to be sent, tell us that there was centralized political control of rural production. At the same time, the defensive, or at least intimidating, nature of the building suggests that this could not be taken entirely for granted.

\footnotetext{
${ }^{82}$ Levels II-I. Valtz 2002-2003: pl. 149.

${ }^{83}$ Sternitzke, forthcoming: pl. 116.

${ }^{84}$ Compare with Armstrong 1993: pls. $72-4$ and 79.

${ }^{85}$ Compare with Nippur Levels III-II. Armstrong 1993: pls. $81 \mathrm{~g}$ and $82 \mathrm{a}$.

${ }^{86}$ Another possible candidate for a regional centre is Tell Deheila, recorded by Wright as EP-34, a short-lived 45 ha
}

site $c .16 \mathrm{~km}$ to the west of Tell Khaiber, lying on the Eridu channel of the Euphrates and dated to late in the Old Babylonian period (Wright 1981: 330). Al-Dafar has recently proposed that it may have been the capital of the Sealand Dynasty (Al-Dafar 2015).

${ }^{87}$ Stone 1977. 
Richardson has drawn attention to the many "military communities located out in the countryside" in the Late Old Babylonian period, which he suggests may have gone on to become more autonomous and self-sufficient. ${ }^{88}$ This would fit well with what we know about Tell Khaiber so far, with the caution that we have still to investigate most of those parts of the mound not covered by the Public Building, and we have still to complete micromorphological and environmental analyses. So far, however, the picture of life in and around the settlement that is suggested by the texts is largely corroborated by the material culture we have examined: this was a working environment, with no clear indication of displayed wealth or organised religious practice. The artefacts confirm that whatever the Public Building was for, it was not a temple. And while it may have included one or more residential suites, it was not a palace. The pottery assemblage, with its lack of elaborate vessel types, shows us everyday, routine patterns of behaviour rather than occasions of ceremony or lavish hospitality. The presence of weapons, both in the Public Building and in the Private Houses nearby, reflects the defensive appearance created by the towers. Women and children were present at some point, as confirmed by infant and female burials that post-date the occupation levels under investigation, but this was surely no dwelling for priestesses or royalty, but a place of business. We have some of the details of that business, but are still searching for its place in the overall political economy of southern Babylonia at this interesting time of change and re-alignment.

\section{Bibliography}

Al-Dafar, A. 2015. Shadow States: The Archaeology of Power in the Marshes of Southern Mesopotamia (Ph.D. thesis; New York: State University of New York at Stony Brook).

Al-Gailani Werr, L. 1988. Cylinder Seals Made of Clay. Iraq 50: 1-24.

Armstrong, J. A. 1993. Chapter 3. Pottery. Pp. 67-78, in R. Zettler (ed.), Nippur III: Kassite Buildings in Area $W C-1$. Chicago: Oriental Institute of the University of Chicago.

Armstrong, J. A. and H. Gasche. 2014. Mesopotamian Pottery: A Guide to the Babylonian Tradition in the Second Millennium B.C. Chicago: Oriental Institute of the University of Chicago.

Assante, J. 2002. Style and Replication in 'Old Babylonian' Terracotta Plaques: Strategies for Entrapping the Power of Images. Pp. 1-29, in O. Loretz (ed.), Ex Mesopotamia et Syria Lux: Festschrift für Manfried Dietrich zu seinem 65. Geburtstag. Alter Orient und Altes Testament 281. Munich: Ugarit Verlag.

Calderbank, D. and J. Moon. 2016. A Ceramic Assemblage of the Early Literate Periods from Sumer. Pp. 73-83, in Y. Heffron, A. B. Stone and M. J. Worthington (eds.), At the Dawn of History: Ancient Near Eastern Studies in Honour of J. Nicholas Postgate. Winona Lake, IN: Eisenbrauns.

Charpin, D. 2004. Histoire politique du Proche-Orient amorrite (2002-1595). Pp. 25-484 in D. Charpin, D. O. Edzard, and M. Stol, Mesopotamien: Die altbabylonischen Zeit. Orbus Biblicus et Orientalis 160/4. Fribourg: Academic Press/Göttingen: Vandenhoeck and Ruprecht.

Clayden, T. 2009. Eye-stones. Zeitschrift für Orient-Archäologie 2: 36-86.

Courty, M. A. and V. Roux. 1995. Identification of Wheel Throwing on the Basis of Ceramic Surface Features and Microfabrics. Journal of Archaeological Science 22: 17-50.

Dalley, S. M. 2009. Babylonian Tablets from the First Sealand Dynasty in the Schoyen Collection. Cornell University Studies in Assyriology and Sumerology 9. Bethesda, MD: CDL Press.

- 2010. Administration in Texts from the First Sealand Dynasty. Pp. 61-68, in L. Kogan, N. Koslova, S. Loesov, and S. Tishchenko (eds.), Proceedings of the 53e Rencontre Assyriologique Internationale Vol. 2: City Administration in the Ancient Near East. Winona Lake, IN: Eisenbrauns.

Faivre, X. 1995. Le recyclage des tablettes cunéiformes. Revue d'Assyriologie 89: 57-66.

Gabutti, A. 2002-2003. La Ceramica dei Livelli VIb-III. Pp. 87-263, in G. Bergamini, A. Gabutti and E. Valtz (eds.), La Ceramica di Tell Yelkhi. Mesopotamia 37-38.

Gasche, H. 1989. La Babylonie au $17^{e}$ siècle avant notre ère: approche archéologique, problèmes et perspectives. Mesopotamian History and Environment, Series II, Memoirs 1. Ghent: University of Ghent.

Gasche, H., J. A. Armstrong, S. W. Cole, and V. G. Gurzadyan. 1998. Dating the Fall of Babylon. A Reappraisal of Second-Millennium Chronology. Mesopotamian History and Environment, Series II, Memoirs 4. Ghent: University of Ghent/Chicago: Oriental Institute of the University of Chicago.

Heginbotham, A., J. Bassett, D. Bourgarit, C. Eveleigh, L. Glinsman, D. Hook, D. Smith, R. J. Speakman, A. Shugar and R. Van Langh. 2015. The Copper CHARM Set: A New Set of Certified Reference

${ }^{88}$ Richardson 2005: 282. 
Materials for the Standardization of Quantitative X-ray Fluorescence Analysis of Heritage Copper Alloys. Archaeometry 57/5: 856-68.

Hill, H., Th Jacobsen and P. Delougaz. 1990. Old Babylonian Public Buildings in the Diyala Region. OIP 98. Chicago: Oriental Institute of the University of Chicago.

Huot, J.-L. 2003. Larsa: travaux de 1987 et 1989. Beirut: Institut français d'archéologie du Proche-Orient.

Jahn, B. 2005. Altbabylonische Wohnhäuser. Eine Gegenüberstellung philologischer und archäologischer Quellen. Orient-Archäologie 16. Rahden: Leidorf.

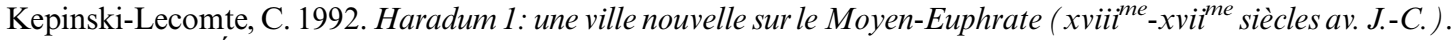
Paris: Éditions recherche sur les civilisations.

Mauer, I. 1983. Agriculture of the Old Babylonian Period. Journal of the Ancient Near Eastern Society 15: 63-78.

Miglus, P. 1999. Städtische Wohnarchitektur in Babylonien und Assyrien. Baghdader Forschungen 22. Mainz am Rhein: von Zabern.

McAnany, P. A. and N. Yoffee (eds.). 2010. Questioning Collapse: Human Resilience, Ecological Vulnerability, and the Aftermath of Empire. Cambridge: Cambridge University Press.

Moorey, P. R. S. 2004. Ancient Near Eastern Terracottas in the Ashmolean Museum. http://www.ashmolean.org/ ash/amocats/anet/. Accessed 15/12/2015.

Postgate, J. N. 2014. Bronze Age Bureaucracy: Writing and the Practice of Government in Assyria. Cambridge: Cambridge University Press.

Pournelle, J. 2003. Marshland of Cities: Deltaic Landscapes and the Evolution of Early Mesopotamian Civilization, Ph.D. diss. University of California, San Diego.

Richardson, S. 2005. Trouble in the Countryside ana tarsi Samsuditana: Militarism, Kassites, and the Fall of Babylon I. Pp. 273-89, in W. H. van Soldt (ed.), Ethnicity in Ancient Mesopotamia, Papers Read at the $48^{\text {th }}$ Rencontre d'Assyriologie Internationale. Leiden: Netherlands Institute for the Near East.

Roaf, M. 2012. The fall of Babylon in 1499 NC or 1595 MC. Akkadica 133: 147-74.

Robson, E. 2004. Accounting for Change: The Development of Tabular Book-keeping in Early Mesopotamia. Pp. 107-44, in M. Hudson and C. Wunsch (eds.), Creating Economic Order: Record-keeping, Standardization, and the Development of Accounting in the Ancient Near East. International Scholars Conference on Ancient Near Eastern Economies 4. Bethesda, MD: CDL Press.

- 2008. Mathematics in Ancient Iraq: A Social History. Princeton, NJ: Princeton University Press.

Rositani, A. 2011. Harvest Texts in the British Museum. Revista degli Studi Orientali, 82, Suppl. 1. Rome: Università "La Sapienza" Dipartimento di Studi Orientali.

Roux, V. and M. Courty. 1998. Identification of Wheel-Fashioning Methods: Technological Analysis of $4^{\text {th }}-3^{\text {rd }}$ Millennium BC Oriental Ceramics. Journal of Archaeological Science 25: 747-63.

Sassmannshausen, L. 2001. Beiträge zur Verwaltung und Gesellschaft Babyloniens in der Kassitenzei. Baghdader Forschungen 21. Mainz am Rhein: von Zabern.

Sternitzke, K. Forthcoming. Babylon im 2. Jahrtausend vor Christus. Die archäologischen Befunde der altbabylonischen und kassitischen Zeit aus den Deutschen Grabungen von 1899-1917.

Stone, E. C. 1977. Economic Crisis and Social Upheaval in Old Babylonian Nippur. Pp. 267-89, in T. Cuyler Young and L. D. Levine (eds.), Mountains and Lowlands: Essays on the Archaeology of Greater Mesopotamia. Bibliothecha Mesopotamica 7. Malibu, CA: Undena Publications.

Tanret, M. 2002. Per aspera ad astra: l'apprentissage du cunéiforme à Sippar-Amnānum pendant la période paléobabylonienne tardive. Mesopotamian History and Environment, Series III, Texts I/2. Ghent: University of Ghent.

Valtz, E. 2002-2003. La Ceramica dei Livelli II e I. Pp. 265-320, in G. Bergamini, A. Gabutti and E. Valtz (eds.), La Ceramica di Tell Yelkhi. Mesopotamia 37-38.

Veldhuis, N. 2014. History of the Cuneiform Lexical Tradition. Guides to the Mesopotamian Textual Record 6. Münster: Ugarit Verlag.

van As, A. and L. Jacobs. 1992. The Work of the Potter in Mesopotamia during the Second Millennium B.C. MRS Proceedings 267: 529-44.

van de Mieroop, M. 2015. A History of the Ancient Near East, ca. 3000-323 BC. 3rd ed. London: Wiley.

van Ess, M. 2014. Characteristics of Middle Babylonian Pottery Production as Mirrored on Old Babylonian Pottery - Continuity or Change? Pp. 333-83, in M. Luciani and A. Hausleiter (eds.), Recent Trends in the Study of Late Bronze Age Ceramics in Syro-Mesopotamia and Neighbouring Regions: Proceedings of the International Workshop in Berlin, 2-5 November 2006. Rahden: Leidorf.

van Koppen, F. 2010. The Old to Middle Babylonian Transition: History and Chronology of the Mesopotamian Dark Age. Aegypten und LevantelEgypt and the Levant 20: 453-63.

van Lerberghe, K. and G. Voet. 2009. A Late Old Babylonian Temple Archive from Dur-Abiešuh. Cornell University Studies in Assyriology and Sumerology 8. Bethesda, MD: CDL Press.

Wiggermann, F. A. M. 2000. Agriculture in the Northern Balikh Valley: The Case of Middle Assyrian Tell Sabi Abyad. Pp. 171-231, in R. M. Jas (ed.), Rainfall and Agriculture in Northern Mesopotamia. Leiden: Netherlands Historical-Archaeological Institute in Istanbul. 
Woolley, C.L. and M. E. L. Mallowan. 1976. Ur Excavations Vol. VII: The Old Babylonian Period. London: British Museum.

Wright, H. T. 1981. The Southern Margins of Sumer: An Archaeological Survey of the Areas of Eridu and Ur. Pp. 295-338, in R. M. Adams, Heartland of Cities. Chicago: University of Chicago Press.

Yoffee, N. and G. L. Cowgill. 1988. The Collapse of Ancient States and Civilizations. Tucson: University of Arizona Press.

\section{Stuart Campbell}

The University of Manchester

Oxford Rd

Manchester M13 9PL

stuart.campbell@manchester.ac.uk

Jane Moon \& Robert Killick

Ur Region Archaeology Project

Upper House

Stoke Saint Milborough

Ludlow

SY8 2EJ

jm@urarchaeology.org

rk@urarchaeology.org

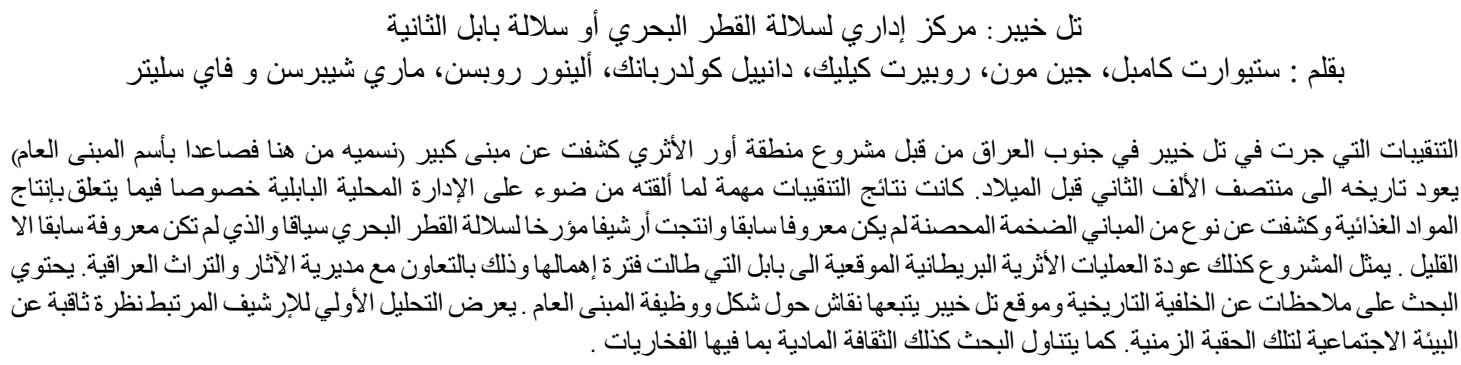

